\title{
Identification and visualization of the intellectual structure and the main research lines in nanoscience and nanotechnology at the worldwide level
}

\author{
Teresa Muñoz-Écija (1) • Benjamín Vargas-Quesada $(\mathbb{D} \cdot$ \\ Zaida Chinchilla-Rodríguez (i)
}

Received: 29 July 2016/Accepted: 29 December 2016/Published online: 11 February 2017

(C) The Author(s) 2017. This article is published with open access at Springerlink.com

\begin{abstract}
The aim of this paper is to make manifest the intellectual and cognitive structure of nanoscience and nanotechnology (NST) by means of visualization techniques. To this end, we used data from the Web of Science (WoS), delimiting the data to the category NST during the period of 2000-2013, retrieving a total of 198,275 documents. Through direct author citation of these works, we identified their origins and the seminal papers, and through word co-occurrence extracted from the titles and abstracts, the main lines of research were identified. In view of both structures, we may affirm that NST is a young scientific discipline in constant expansion, needing time to establish its foundations but showing a strongly interdisciplinary character; its development is furthermore dependent upon knowledge from other disciplines, such as physics, chemistry, or material sciences. We believe that this information may be very useful for the NST scientific community, as it reflects a
\end{abstract}

T. Muñoz-Écija • B. Vargas-Quesada

Department of Information and Communication, Faculty of Communication and Documentation, SCImago Research Group, University of Granada, Campus de Cartuja s/n, 18071 Granada, Spain

T. Muñoz-Écija

e-mail: teresamunyozecija@gmail.com

B. Vargas-Quesada

e-mail: benjamin@ugr.es

Z. Chinchilla-Rodríguez $(\bowtie)$

CSIC, Institute of Public Goods and Policies (IPP), SCImago

Research Group, Albasanz 26-28, 28037 Madrid, Spain

e-mail: zaida.chinchilla@csic.es large-scale analysis of the research lines of NST and how research has changed over time in the diverse areas of NST. This study is moreover intended to offer a useful tool for the NST scientific community, revealing at a glance the main research lines and landmark papers. Finally, the methodology used in this study can be replicated in any other field of science to explore its intellectual and cognitive structure.

Keywords Co-words $\cdot$ Direct citation $\cdot$ Intellectual structure $\cdot$ Research trends $\cdot$ Historical roots . Nanoscience \& Nanotechnology · Scientometrics

\section{Introduction}

Nanoscience and nanotechnology (NST) comprise the study, design, creation, synthesis, manipulation, and application of materials, devices, and functional systems by means of the control of the material at the nanoscale, as well as the exploitation of phenomena and properties of material at the nanoscale. It is a discipline that appears in the second half of the twentieth century, when Richard P. Feynman (1960) referred to the possibilities offered by the manipulation of material at the atomic scale. The discovery of the scanning tunneling microscope (Binnig and Rohrer 1983) in the 1980s opened the gates to the development of NST, as it allowed the scientific community to obtain new materials and minute machinery.

According to the literature, only in the past decade has NST taken off on an exponential voyage due to the 
advancements it holds for industry, health, the environment, and national security (Huang et al. 2011). Yet, negative social and environmental implications have also come to light, as well as a lack of knowledge about the risks that many of its applications could entail (Seaton and Donaldson 2005).

Many are the works that have studied the scientific literature in NST. For example, the study run by Braun et al. (1997) established a clearly exponential growth of the NST scientific production that started in the early 1990s on the basis of a dataset with the prefix nano in the title of science and technological journal papers (4152 papers) from Science Citation Index (ISI) in the period of 1986-1995. A year later, Meyer and Persson (1998) characterized nanotechnology showing its interdisciplinary nature. Using the same approach as Braun et al. (1997), they determined that the major rate growth of nano-paper is in natural and multidisciplinary science, while the field of engineering and material and life science would be less important in view of their negative rate of growth. The growth of NST has been registered both as scientific publications and as patents. Hence, the bibliometric perspective is ideal for observing scientific activity in this discipline, with its interdisciplinary and multidisciplinary characters (Schummer 2004) and its widespread economic and social implications.

Kostoff et al. (2006b) appraised the growth of the nanotechnology research literature in the Science Citation Index, from 4552 articles in 1991 to 33,060 articles in 2004, and another study pointed out that "Global nanotechnology research article production has exhibited exponential growth for more than a decade". They studied more than 65,000 records related to NST in the Science Citation Index/ Social Science Citation Index (SCI/SSCI) in 2005 (Kostoff et al. 2007b). Porter et al. (2008) displayed the nano research publication activity from 1990 to 2006 from the Science Citation Index, finding growth in the nano research activity to be higher from the year 2000 onward. The number of papers in NST contained in WoS journals shows a steady increase since 2000 (Chen et al. 2013). Another study concludes that the number of nanotechnology journals has been growing steadily since the late 1990s (Grieneisen 2010). Such growth is also reflected in the Scopus database, where the documents published show a nearly threefold growth of NST world share output. The main growth spurt is between 2007 and 2013, a period when its world share output practically doubled (Chinchilla-Rodríguez et al. 2016a).

Beyond matters of growth, in recent years, many researchers have conducted scientometric analysis to define nanotechnology and capture its scope by using lexical queries (Porter et al. 2008; Huang et al. 2011; Grieneisen and Zhang 2011; Arora et al. 2013, 2014); to identify all disciplines that NST encompasses exhibiting the interdisciplinary of NST (Porter and Youtie 2009); to explore the interdisciplinary characteristics of NST and investigate its intellectual structure (Jo et al. 2016); to give a global overview of the infrastructure of the global nanotechnology literature through most cited authors, journal, and papers, and prolific authors, journal institutions, and countries (Kostoff et al. 2006b); to study the network of citation in nanotechnology for patents, institutions, countries, and technology fields (Li et al. 2007); to identify the core papers in NST and describe its genealogy (Kostoff et al. 2006a); to examine the cognitive structure, multidisciplinarity, and evolution of NST (Milojević 2012); or to examine the research paper and patents involved in the coming generation of active nanotechnologies to delineate phases and possible emerging research directions (Suominen et al. 2016).

In addition, bibliometric techniques have helped to study the development of certain subfields or subjects within NST, for instance carbon nanotubes (MunozSandoval 2014), carbon nanostructures (Terekhov 2015), nanoparticle generation by laser ablation in liquids (Barcikowski et al. 2009), nanotoxicology (Ostrowski et al. 2009), nano-energy (MenéndezManjón et al. 2011; Guan and Liu 2014), or microelectromechanical systems (MENS) (Hu and Liu 2015).

Other works have applied bibliometric techniques to analyze the evolution and position of NST in the international context, so as to gauge the scientific performance of countries (Chen et al. 2013; ChinchillaRodríguez et al. 2016a); to compare developed and developing countries (Jafari and Zarghami 2016); to highlight activity and visibility in the global landscape of some countries, among them Russia (Terekhov 2012) or the Siberian Branch of the Russian Academy of Science (Lavrik et al. 2015), in Latin America (Invernizzi et al. 2015; Chinchilla-Rodríguez et al. 2016b), in Mexico (Lau et al. 2014), in Venezuela (López Cadenas et al. 2011), or Pakistan (Bajwa and Yaldram 2012); to evaluate the productivity, dominant research topics, and diffusion patterns in Russia, China, and India 
using papers from WoS and patents from US Patent and Trademark Office (USPTO) (Liu et al. 2009); to identify the risky nanomaterials that the nano-environmental, health, and safety community might examine through study of patent literature from USPTO and World Intellectual Property Organization (WIPO) and the Project on Emerging Nanotechnologies consumer product database (Leitch et al. 2012); or to identify growth trends, research topics, and the evolution in National Science Foundation (NSF) funding and commercial patenting activities at USPTO (Huang et al. 2006).

Among the array of bibliometric techniques available today, science mapping is particularly useful for analyzing and visualizing the social and intellectual structure or dynamics of scientific research fronts (Braam et al. 1991a, b; Noyons et al. 1999; Börner et al. 2003). These representations, dating back to the seventies, allow users to explore relationships involving the selected unit of analysis (Small 1973; Small and Griffith 1974; Small and Sweeney 1985; Small et al. 1985). In the 1980s, they underwent a controversial period of development and virtual brainstorming to confirm their validity (Leydesdorff 1987; Hicks 1987; Tijseen et al. 1987). This led to a slowdown in the absorption of scientific policy in the 1990s, when more user-friendly interfaces became commonplace. In the past 10 years, their use has been extended and their utility is a matter of consensus, due largely to the greater availability of data, with important expert contributions in the field of computation specializing in information visualization (Börner et al. 2003). Today's science maps have benefited from a combination of new algorithms, the enhanced potency of calculation, and the robustness of results, as one can generate and guarantee a stable template at the worldwide level to be used as the basis for analysis (MoyaAnegón et al. 2004, 2007; Boyack et al. 2005; Leydesdorff and Rafols 2009; Rafols et al. 2010).

The development of techniques such as overlay maps (Rafols et al. 2010) makes it possible to generate such stable templates of scientific maps at the global level, for their later use to compare aspects of an organization, a field of research or the scientific output contained in databases such as the Web of Science (Thomson Corporation 2015b) or Scopus (Elsevier 2015). The cognitive structure of a scientific domain may thereby be analyzed in a geographic sense, or to perceive its evolution and the emerging lines of research that may be a priority for the economic policy of a government (Leydesdorff and Rafols 2011; Leydesdorff et al. 2015).
Such maps can thereafter serve as units of analysis regarding authors, documents, journals, or relevant term/words. Authorship is used to trace the social and intellectual structure (scientific paradigm) of a discipline, field, or specialty (Chen 1999; Garfield et al. 2003). Documents are used to visualize a knowledge domain or to assess research (Small 1999; Noyons et al. 1999). Journals can project a macro view of science or differentiation in a discipline (Leydesdorff 1987; Boyack et al. 2009).

Direct citation networks are considered the most efficient means of exploring how the scientific paradigm of a discipline is built through its own history and development (Garfield et al. 2003; Garfield 2004, 2009). Garfield points out that the most relevant nodes shown in a network constitute a landmark event in the broader development of a knowledge domain.

Although bibliometric techniques use citation analysis to study the yield of a discipline in terms of the impact or strength of influence of research efforts, using citation in the present work has nothing to do with the use (or misuse) of the journal impact factor for the promotion and financing of authors. We do not attempt to analyze the quality of research; citation is merely used to follow the flow of ideas and knowledge recorded as references made by authors when they root or support their ideas in background papers (Narin 1976; Garfield 1979). Mention of a document is a means of manifesting the relationship between a citing work and the cited work at a particular point in the development of research (Sandison 1989; Egghe and Rousseau 1990).

Our perspective with this understanding of citation focuses on identifying research topics or disciplines in cognitive networks and uncovering the intellectual structure of a discipline by the use of direct citation networks where each node represents a piece of knowledge and each link denotes the knowledge flow (Newman 2003). The analysis of citation networks, from a scientometric perspective, can help identify core literature (Potter 1988), retrace the diffusion of ideas or trace the structure of knowledge (Soper et al. 1990), or look at communication patterns, identifying the most influential authors and papers (Lawani 1980). The interpretations brought out through citation analysis applied to books and journals of a specific discipline can also testify as to its historical movement and determinant production at the national or international level (Lawani 1981). 
The use of journal articles - adopted in this works as a single evaluation unit - is based on the notion that journal literature is the most formal channel of communication for scientists (Bellardo 1980) and lies at the heart of scientific and technical communication (Tomajko and Drake 1985), allowing the dissemination of information across geographical borders by scientists in any field of knowledge (Borgman 1989). In no case were journals from WoS used to quantify impact. This journal set was selected because WoS provides mature, reliable source material for mapping science (Leydesdorff et al. 2010).

Co-word analysis is a means of studying the association between the most representative terms of scientific literature, likewise lending the opportunity to obtain further information about the underlying structure and the overt tendencies of a given scientific discipline (Ding et al. 2001; Cantos-Mateos et al. 2012). Words themselves lead us to familiarity with living science and have the capacity to reflect scientific, social, and political contents that pertain to the most controversial domains or least understood emerging areas (CantosMateos et al. 2014). The combination of frequency of appearance of terms, together with the techniques of spatial representation based on multidimensional scaling (MDS), provides us with information about the main research topics or those that prevail over a given period of time.

We can trace co-word analysis back to the 1980 s (Callon et al. 1983; Leydesdorff 1989), when it was described as the best method to know and explain the cognitive structure of a field at the level of research specialties (Small and Griffith 1974; Braam et al. 1991a, b), moreover capable of revealing new developments of a field over time (Peters and van Raan 1993). This type of analysis was applied to polymer chemistry (Callon et al. 1991), to neural network investigation (Van Raan and Tijseen 1993), to information retrieval (Ding et al. 2001), to Information Sciences (Van Den Besselaar and Heimeriks 2006), to the links between opportunistic infections (IOs) and HIV/AIDS (Onyancha and Ocholla 2005), to the Economy (Cahlík and Jiřina 2006), to secure information (Lee 2008), Ecology (Neff and Corley 2009), to biodiversity and conservation (Liu et al. 2011), or to corporate social responsibility (Qin et al. 2016), among others.

It is assumed that NST is an attractive new scientific discipline, in which many researchers, countries, and institutions want to be involved. Its study by the use of different bibliometric, scientometric, or informetric methodologies stands as a sign of the interest that NST holds in the worldwide R\&D context given the many economic benefits for developed and developing countries (Wood et al. 2003) with their variety of impending needs (Beumer 2016).

Our hypothesis stems from the premise that the bibliographic references cited in research papers are an indicator of the influence that they have on the scientific community, conditioning scientific progress and provoking new ideas and subject areas; co-word analysis furthermore marks changes in the different research lines that make up a discipline. Accordingly, our study has a triple objective. Firstly, it aims to detect the origin of and trace the evolution of the intellectual structure of NST by means of the analysis of direct citation of works. Secondly, it attempts to identify and analyze the cognitive structure over time (active research lines) by means of co-word maps to exhibit changes taking place in NST. Thirdly, the methodology described offers another perspective of NST as a discipline by means of citation and co-word analysis.

\section{Materials and methods}

The Web of Science (WoS) was the database utilized to retrieve the set of documents on NST. Up to the time when this study was undertaken, it was the only multidisciplinary and international database containing this category, created in 2005, and composed following the Journal Citation Report (JCR) (Thomson Corporation 2015a) Science Edition 2014 by 73 journals. This source was the foundation of our search strategy. An abbreviated journal title query was subsequently designed and entered into the WoS database search engine for the version Science Citation Index Expanded 2014 (Appendix A).

Evidently, the NST category in WoS does not cover all the journals that publish articles about NST. It includes only the best journals. For this reason, we decided to design our search strategy using the JCR journals in the NST category, as the top journals of a discipline can be viewed as a sound tool for scientific evaluation (Garfield 1972, 1980). Although the number of NST journals has shown steady growth since the late 1990s, many articles about NST are also published in multidisciplinary science journals such as Science or Nature, or in highly specific discipline journals such as Angewandte Chemie or Applied Physics Letters (Grieneisen 2010). 
This is because many NST research lines in NST are not yet mature - still in the launching stage. As we needed to choose the journal set that would best represent NST as a discipline, we looked to JCR, whose journals might contain references to articles published elsewhere, that is, not exclusively in specialized NST journals.

Our search strategy used the field Publication Name, as this field is less problematic than others; it can retrieve more than 100,000 documents when combined with other fields (Arencibia-Jorge et al. 2009), yet in this case, it was limited by the time frame of study.

The period 2000-2013 was selected based on the papers of Grieneisen and Zhang (2011), who state that since 1998, nanoscale studies have grown in alarming proportions in the entire body of research. In addition, the choice of a short time period allows for the published documents to play on an equal level with the documents published previously, which may have received numerous citations; in short time periods, the documents involved are all recent and have not yet generated substantial citation (Kostoff et al. 2008). Subsequently, we chose 2013 as the last year for the sampling time frame.

The discovery of graphene in 2004, the design of new programs and software like Gaussian (2003 or 2009) or SIESTA in 2002, the use of nanowire for solar cells or as nanosensors for the detection of biological and chemical species in 2001, the characterization of gold nanoparticles in 2004, etc., these are only a few examples of core papers in NST published in the first decade of this century.

In June of 2015, we launched our search into the WoS database search engine. The number of retrieved documents (Fig. 1) from 2000 to 2013 was 198,275 and includes the following types: articles $(187,949)$, proceedings $(26,606)$, reviews (4066), editorial materials (3116), new items (1378), corrections (1223), letters (386), biographical items (80), meeting abstracts (70), book chapters (6), bibliographies (5), and reprints (2).

Intellectual structure and detection of seminal papers

Citation-Assisted Background (CAB) (Kostoff and Shlesinger 2005) was used to identify seminal papers. $\mathrm{CAB}$ is based upon the assumption that seminal documents tend to be highly cited by the active researchers who belong to a specific scientific discipline; hence, any reference to these seminal documents will tend to be positive (Kostoff and Shlesinger 2005; Kostoff et al. 2006a). A file was generated where all downloaded documents were combined and a citation analysis was performed to identify the most cited documents of the dataset, using CitNetExplorer (Van Eck and Waltman 2014b), for visualizing and analyzing citation networks of scientific publications. This tool was used to create and visualize the intellectual network. The uncovered network featured a static structure that relied on papers as units of analysis and citations as units of measure.

The values applied to visualize information must range between 25 and 125 (White 2003). In our case, a total of 80 most-cited papers was the cutoff established, because a higher number of nodes would show too many relationships, and the viewer would perceive excessive information and an overlap of labels. This problem is known as an incomprehensible "clutter of links".

After identifying the 80 most cited documents, we downloaded the most-cited documents which were not included in the initial dataset for one of two reasons: (a) either the documents had been published in journals that did not belong to the category of JCR NST or (b) the documents had been published before the year 2000. To download these most-cited documents from WoS, we executed different searches in the Title field, i.e., each most-cited title paper was tracked down in the Title field in WoS. This proved to be a crucial step in the process of generating the network using CitNetExplorer software. Otherwise, the nodes would have appeared as isolated nodes instead of as related nodes.

After this process, all the new downloaded papers were input into the initial dataset and a new citation analysis was performed, again using CitNetExplorer, showing the 80 most cited papers identified above and their relationships.

We should point out that downloading the most cited papers that were not included in the initial data set proved to be an essential step in our methodology, enabling us to explore the intellectual structure of NST and the relations between its nodes. If our network had only shown the most cited documents, no relationship with documents published before the year 2000 or with documents not published in JCR NST journals would have become apparent.

For the detection of the different clusters, CitNetExplorer applies an algorithm based on a variant of the modularity, by virtue of which the documents appear grouped in different clusters depending on the function of the distance in between them, so that the documents with a high degree of relatedness are found 
Fig. 1 NST-retrieved documents from WoS and relevant terms

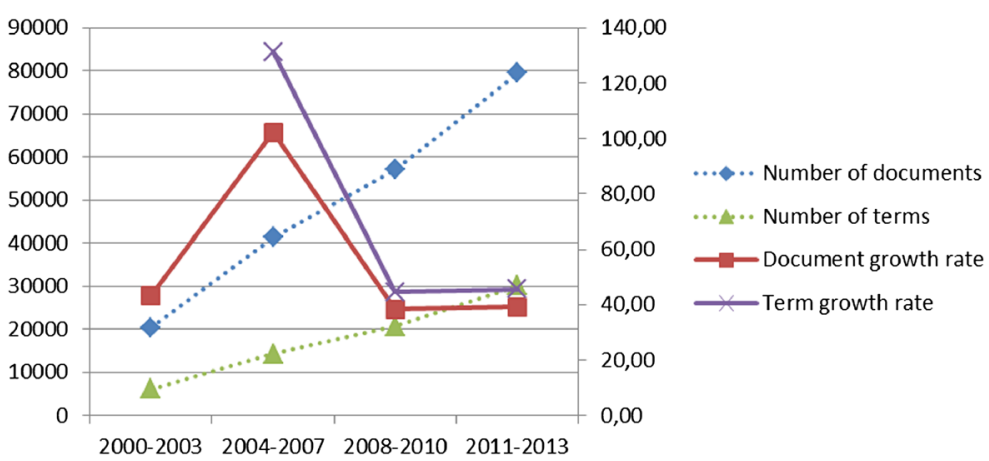

next to each other, and therefore form part of one same cluster (Van Eck and Waltman 2014a).

\section{Cognitive structure}

Co-word maps allow us to represent the cognitive structure of a discipline, identifying the research lines that form it and detecting future lines of research by means of clustering techniques (Callon et al. 1986; He 1999).

The detection of the main research lines and their evolution using longitudinal maps or networks reveals the best consolidated lines as well as the emergent ones. Used here as the unit of analysis were the works contained in the titles and the abstracts of the set of documents retrieved (Fig. 1); their co-occurrence as units of measurement; and, as the tool for the generation and visualization of the network, VOSviewer software (Van Eck et al. 2010; Van Eck and Waltman 2015).

In an effort to control the acronyms presented by many of the terms contained in the data file, we generated a thesaurus ${ }^{1}$ with the most frequent acronyms. The second function of this thesaurus was to eliminate the terms of little significance contained in the documents. However, no thorough normalization of the data was carried out, which might have distorted the reality of our unit of analysis (words).

The number of words in each map increased steadily due to the rise in scientific production over the past decade. To avoid excessive noise and show only the most significant terms, a minimum occurrence threshold of 5 was established (a term was shown if it appeared at least five times). Furthermore, the VOSviewer default setting was used, meaning that $60 \%$ of the most relevant

\footnotetext{
${ }^{1}$ This thesaurus was generated by a text editor, and then imported to VOSviewer. It contains approximately 2000 equivalencies and is available at $h$ ttp://www.ugr.es/local/benjamin/thesaurus-N\&N.txt.
}

terms were displayed for each period. At any rate, a cluster should have at least ten words to be represented.

To detect the different clusters, the VOSviewer algorithm - an improved version of multidimensional scaling (MDS) - was used. This enabled us to avoid problems associated with MDS visualization such as generating circular representations or displaying the most relevant terms in the center of the representations (Van Eck and Waltman 2010).

The creation of a single map might entail some loss of information about changes in the main research lines of a discipline over time. In addition, because the number of documents per year has increased dramatically since 2000, new research trends have sprung up. With the utmost objective of representing the evolution of the cognitive structure of NST over time, without provoking a loss of structural information, we opted to make maps applying a temporary division into four sub-periods: longer periods (4 years) for the first temporal windows (2000-2003 and 2004-2007) and shorter ones for the following (3-year) periods (2008-2010 and 2011-2013) (Vargas-Quesada et al. 2010; Moya-Anegón et al. 2006). This basically resolved the problem related with the number of terms that made up each map, since the number of documents that comprised scientific output in NST in 2000-2007 is inferior to the figure for 20082010. Therefore, the generation of maps covering the same number of years can be said to mask reality in the displays owing to this difference in the number of terms intervening.

Each one of the circles depicted in the maps makes reference to a term, its size being proportional to the number of co-occurrences with other terms. The proximity of some terms with others indicates the association or similarity existent among them, that is, the nearer two terms are to each other, the stronger their association. To the contrary, two terms far from each other point to a low 
level of mutual association. The color of the circles indicates belonging to a cluster, and every cluster or grouping, with its nodes, is therefore depicted in a different color.

\section{Results and discussion}

The average growth of NST scientific output in the time frames established for creating our maps was $55.78 \%$. However, the period of 2004-2007 showed an outstanding growth rate of $102.17 \%$, followed by years 2000 2003 (43.32\%), 2011-2013 (39.20\%), and 2008-2010 $(38.41 \%)$. As for the annual growth rate, 2007 is the most remarkable year, witnessing an increase of $41.24 \%$ in NST output, followed by 2006 , with $25.02 \%$, and 2003 , with a growth rate of $24.74 \%$.

Focusing on the evolution of the number of most relevant terms for each period again signals 2004-2007 as the window of greatest growth (131.11\%), after which the figures remain quite stable, from 44.66 to $45.53 \%$.

A comparison of the average growth in the number of documents and the number of terms reveals a peak in the first periods of study, followed by a relatively stable trend in later periods.

Intellectual structure NST—seminal papers

Figure 2 shows the citation network with the 80 most-cited works throughout 2000-2013. The oldest of these papers detected goes back to 1958 , and the most recent one is from 2009. Nodes of the citation network were cited at least 607 times from the dataset with 197,042 documents, leading to a sum total of 1,262,640 references. They appear in seven clusters that were studied selecting the Drill down option of CitNetExplorer, which offers an intuitive way of moving through the colored clusters. The maximum number of nodes in the clusters is 23 and the minimum is 1 , because the nodes that form every cluster have been cited more than 607 times by the dataset.

Blue cluster: Nanochemistry and Nanomedicine (21 nodes)

Inside this cluster (Fig. 3), four different subgroups can be identified. To the right, we find papers by authors Murray et al. (1993), Alivisatos (1996), Decher (1997), Chan and Nie (1998), Bruchez et al. (1998), Peng et al. (2000), Huynh et al. (2002), Yu et al. (2003), Michalet et al. (2005), and Medintz et al. (2005). All of them concentrated their research activities on Quantum dots: composition; shape; size; and spectroscopic, electronic, and thermodynamic attributes. Alivisatos' work is considered the most important in that area, bearing considerable influence on posterior research. In the middle are works related to Supramolecular chemistry. These papers were published by Bohren and Huffman (1983), Kreibig and Vollmer (1995), Kelly et al. (2003), Daniel and Astruc (2004), Love et al. (2005), and Burda et al. (2005). On the left appear papers about Optical and spectroscopic nanoparticle attributes. It is easy to see a major gap between the early work (Johnson and Christy 1972) and the subsequent development around 1997, when interest in this field peaked. All the areas of this cluster are seen to be associated with the research undertaken in Nanochemistry and Nanomedicine.

Orange cluster: Nanomaterial characteristics and manufacturing techniques (13 nodes)

Works of this cluster (Fig. 4) are focused on the study of bottom-up nanomaterial manufacturing techniques, although we can divide the cluster into three sections. Papers on the right explore nanomaterial manufacturing, e.g., involving nanowires or nanobelts. Wagner and Ellis' work in 1964 was the forefather in this field (Wagner and Ellis 1964). Afterward came works by Morales and Lieber (1998), Cui et al. (2001), Pan et al. (2001), Huang et al. (2001), Xia et al. (2003), and Wang and Song (2006), the latter cited because of his review of one-dimensional nanostructures.

On the other side of the map, we find works about the manufacturing of devices to generate power energy or chemicals using electrochemistry techniques. Fujishima (1972) was the pioneer in this area, but it was not until 1991 when Oregan and Grätzel published a work that sorted out the problems suggested by Fujishima, using dye-sensitized colloidal titanium oxide to create efficient and economical solar cells (Oregan and Grätzel 1991). The papers by Hoffmann et al. (1995), Asahi et al. (2001), and Grätzel (2001) address environmental concerns through semiconductor catalysis, using solar irradiation or interior lighting to generate cheap and flexible photovoltaic cells based on nanocrystalline materials and conducting polymer films as a new generation of photoelectrochemical cells. Law's node appears a bit separate from the others because this paper used nanowires as solar cells to further increase their efficacy (Law et al. 2005).

Brown cluster: Physics and Chemistry (18 nodes)

Here (Fig. 5), we find the fundamental research in NST associated with Physics and Chemistry. Physics 


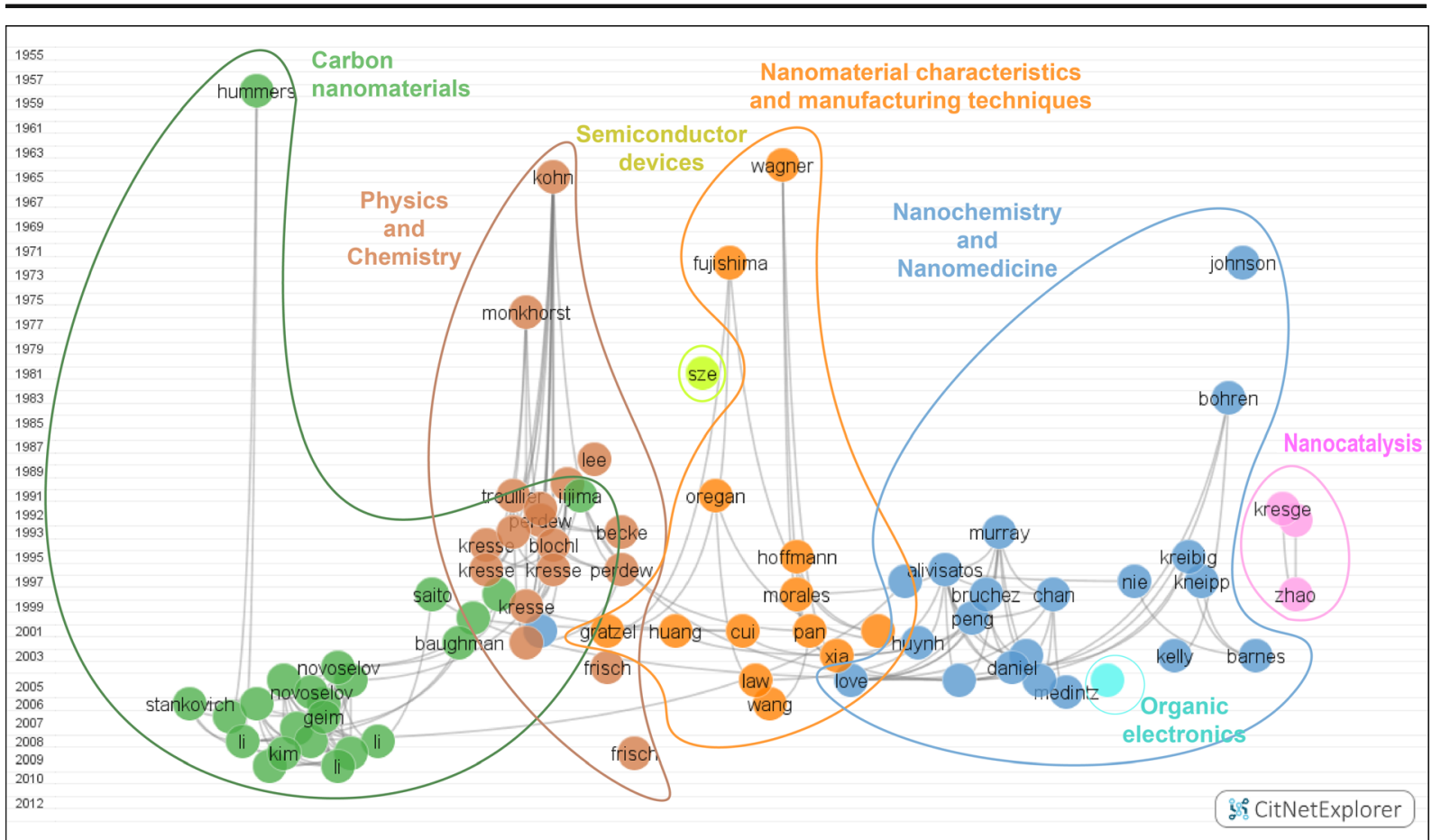

Fig. 2 The 80 most cited document networks in NST. Available in high resolution at: http://www.ugr.es/local/benjamin/maps/Figure-2.png

occupied the right side of the map, and Chemical theory is on the left, in turn divided into two different groups: Quantum chemistry and Computational chemistry.
On the side of Physics, deserving mention is a work from 1965 presenting equations that solved the density functional theory (DFT) (Kohn and Sham 1965), whose

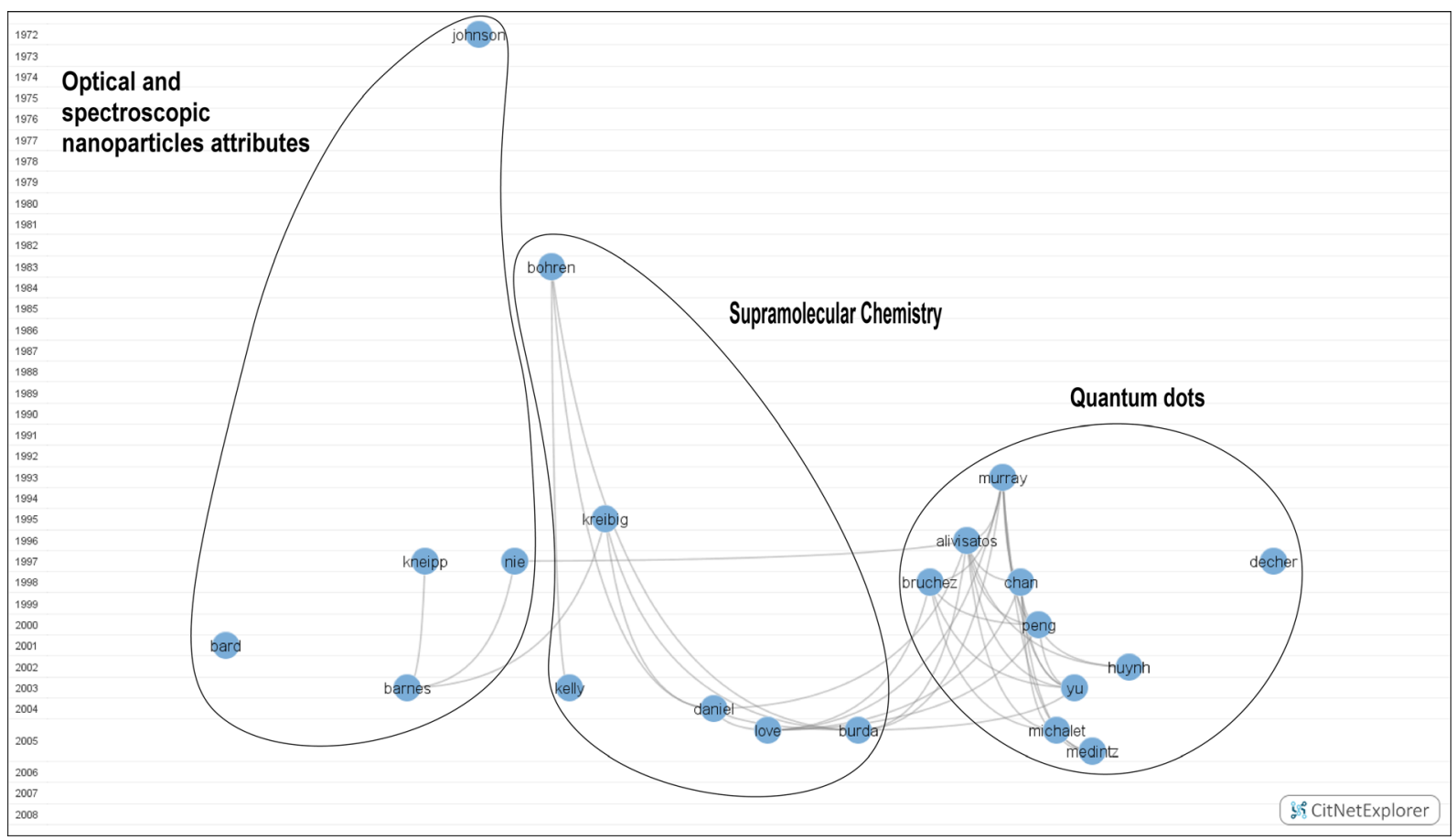

Fig. 3 Nanochemistry and Nanomedicine. Available in high resolution at: http://www.ugr.es/local/benjamin/maps/Figure-3.png 


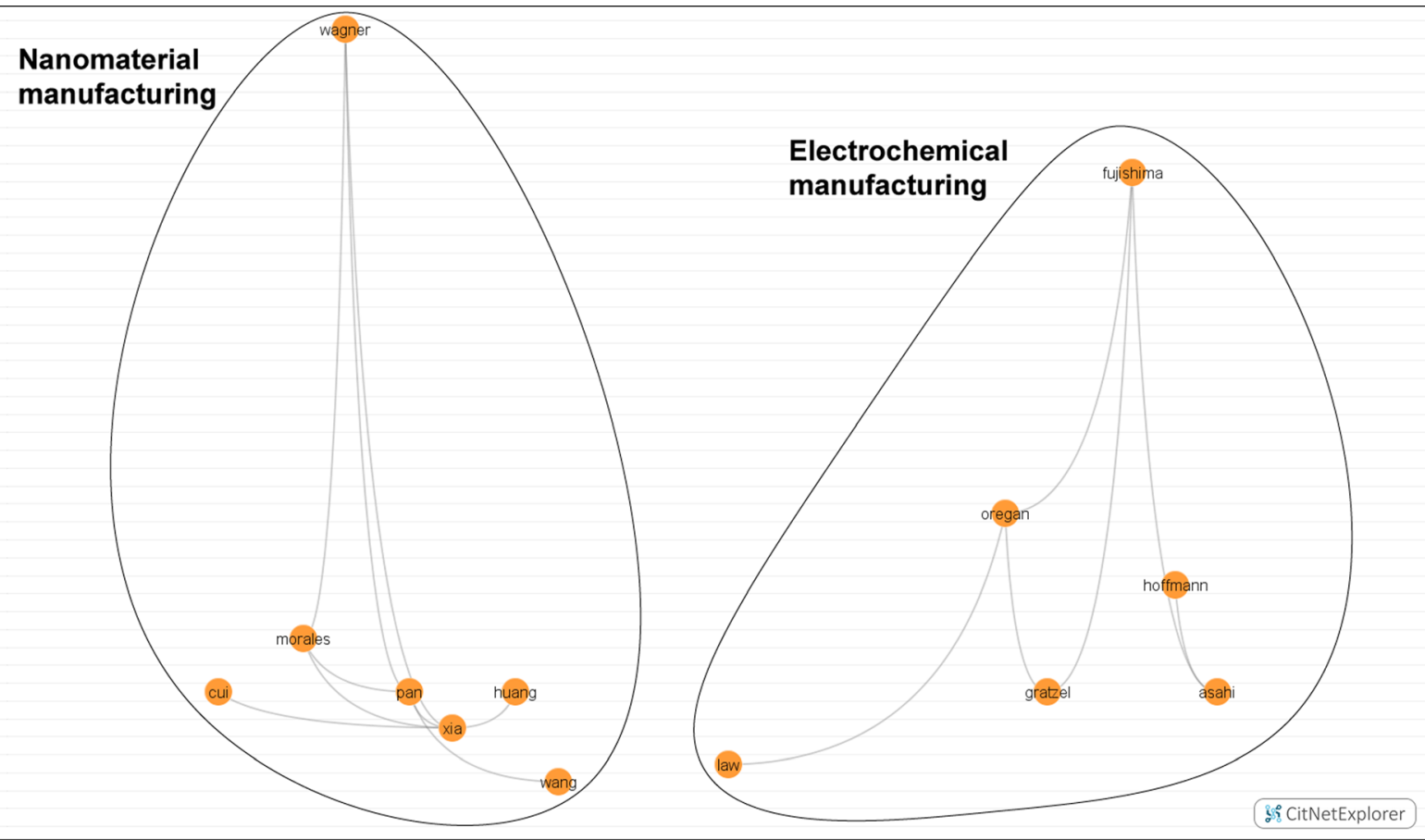

Fig. 4 Nanomaterial characteristics and manufacturing techniques Available in high resolution at: http://www.ugr. es/local/benjamin/maps/Figure-4.png

theorem was published the previous year. However, this theory was modified in 1990 because of its imprecision, especially for chemical applications. Another contribution to DFT is that of Perdew et al. (1996), the second

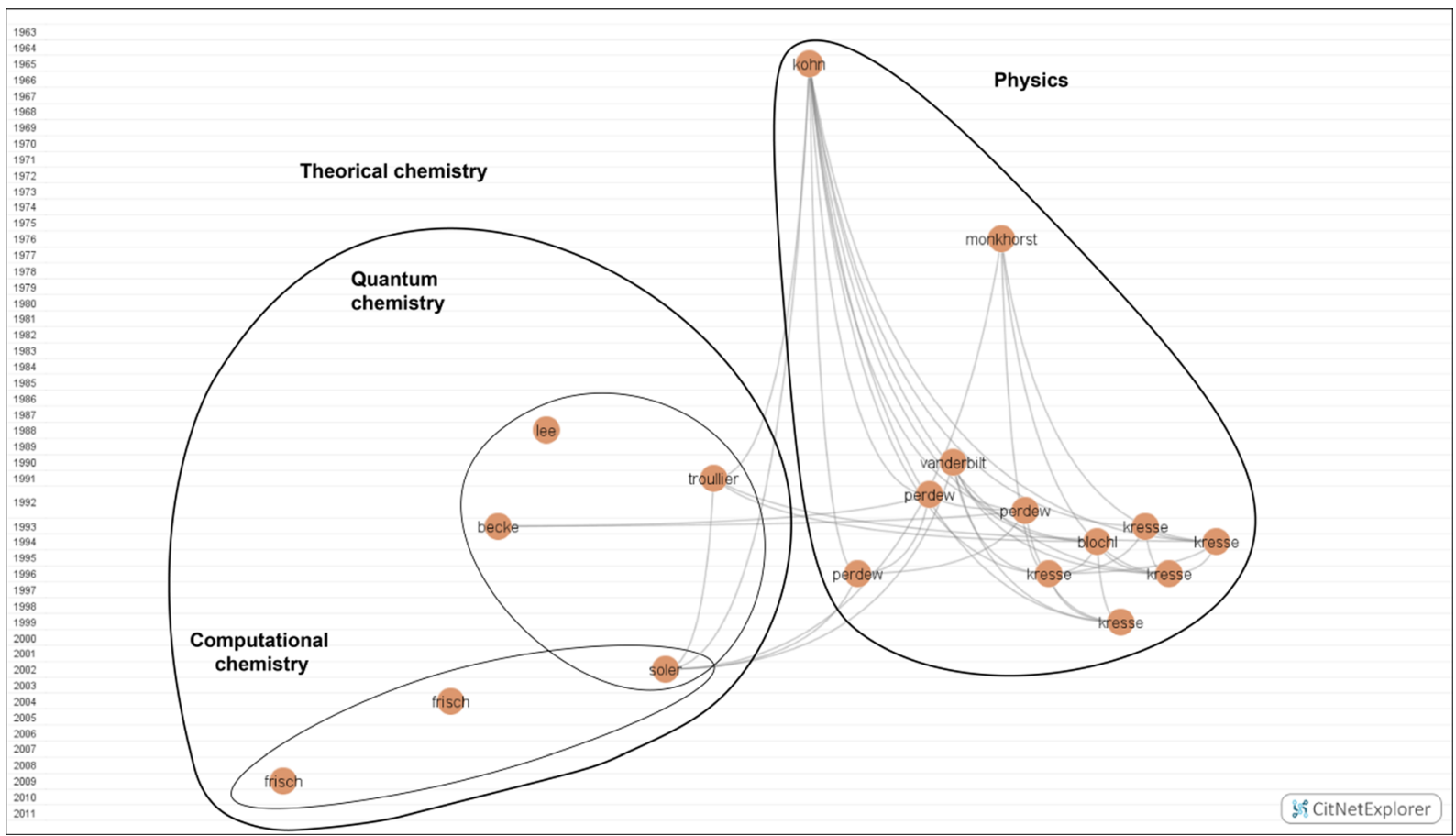

Fig. 5 Physics and Chemistry. Available in high resolution at: http://www.ugr.es/local/benjamin/maps/Figure-5.png 
most cited work in the citation network, about the exact exchange-correlation functional called generalized gradient approximation (the first did not solve Kohn and Sham's equation). In addition, Lee et al. (1988) and Becke's (1993) works encouraged the exchangecorrelation functional.

The projector augmented wave method (PAW) was developed in order to calculate electronic structures through the pseudopotential method and linearized augmented plane-wave method (Blöchl 1994).

Kresse's works contributed to the development of essential principles (ab-initio) of DFT, combining different methods to quickly solve Kohn and Sham's equations (Kresse and Hafner 1993, 1994; Kresse and Furthmüller 1996a, b; Kresse and Joubert 1999). The percentage of citation of these key papers is very high, indeed comprising most of the highly cited works.

On the other side, the quantum chemistry group contains four nodes. Papers by Troullier and Soler are represented on the right. The first explored pseudopotentials, with applications to some materials through plane-wave calculations (Troullier and Martins 1991). Soler and colleagues' work designed a program called Spanish Initiative for Electronic Simulations with Thousands of Atoms (SIESTA) that combined DFT-related methods to calculate electronic structures and ab initio molecular dynamics (Soler et al. 2002). Slightly to the left appear Lee and Becke's works. Lee and colleagues developed a ColleSalvetti correlation energy formula as a functional of the electron density (Lee et al. 1988), while Becke presented an improvement of the thermochemical Kohn-Sham density-functional theories with gradient corrections for exchange-correlations (Becke 1993).

The computational chemistry subgroup is located under the quantum chemistry group. The different software versions of Gaussian (03 and 09) (Frisch et al. 2004, 2009) are displayed in this group. These programs have been used in NST to run a variety of electronic structure calculations and to predict molecular properties and chemical reactions. Soler's work also pertains to this group, as it proposed a computer program to implement SIESTA.

Most nodes here have been highly cited. Hence, it can be said that this is prestigious work presenting ideas or discoveries that proved essential for the development of NST, as it is impossible to study applied science without fundamental research.

Green cluster: Carbon nanomaterials (23 nodes)

This cluster (Fig. 6) reflects a current research boom: carbon nanomaterials, such as nanotubes or graphene.
The first work was published by Hummers and Offeman (1958): graphite was synthesized in order to obtain graphite oxide. Several decades later came the landmark discovery of carbon nanotubes by Iijima (1991), which revolutionized NST and inspired prolific research by Tans et al. (1998), Kong et al. (2000), Baughman et al. (2002), and so on. Nanotubes led to the development of graphene in Novoselov et al. (2004). Nowadays, many basic and applied research efforts are focused on graphene-how to synthesize this nanomaterial and how to handle it without breaking or modifying it or finding new applications according to its electronic, optic, thermal, and mechanic characteristics. Hence, as the map shows, all nodes below the graphene node have dealt with this material.

A glance at the green cluster shows that many nodes have been cited in a short period of time. In other words, work with graphene tends to be highly cited. This new research line shows great promise for the future.

Pink cluster: Nanocatalysis (3 nodes)

Works in this cluster (Fig. 2) involve the synthesis of nanoporous materials and the application of mesoporous (pore size to 2 from $5 \mathrm{~nm}$ ) materials in the synthesis of chemical products, known as nanocatalysis (Kresge et al. 1992; Beck et al. 1992; Zhao et al. 1998).

Light blue cluster: Organic electronics (1 node)

Research on producing photovoltaic power using polymer devices is displayed in this cluster (Fig. 2). In particular, Li and colleagues' work studied photovoltaic polymer cells whose electric characteristics (conductivity) lend them to further applications (Li et al. 2005).

Yellow cluster: Semiconductor devices (1 node)

There is only one node is this cluster: Sze (1981). This work is held to be a main reference in the field of semiconductor devices (Fig. 2).

Cognitive structure - research patterns and emerging trends

This section shows the evolution of NST research from 2000 to 2013 by means of science maps generated with VOSviewer. Tables 1 and 2 make it easy to schematically view the clusters identified, using the VOSviewer algorithm, in the different periods and their relationships with the rest of the clusters.

Tables 3, 4, 5, and 6 present the 15 terms with the highest score (according to VOSviewer) for each cluster and for each period studied. None of these 15 terms is repeated in other periods. Yet, if we increase the cutoff 


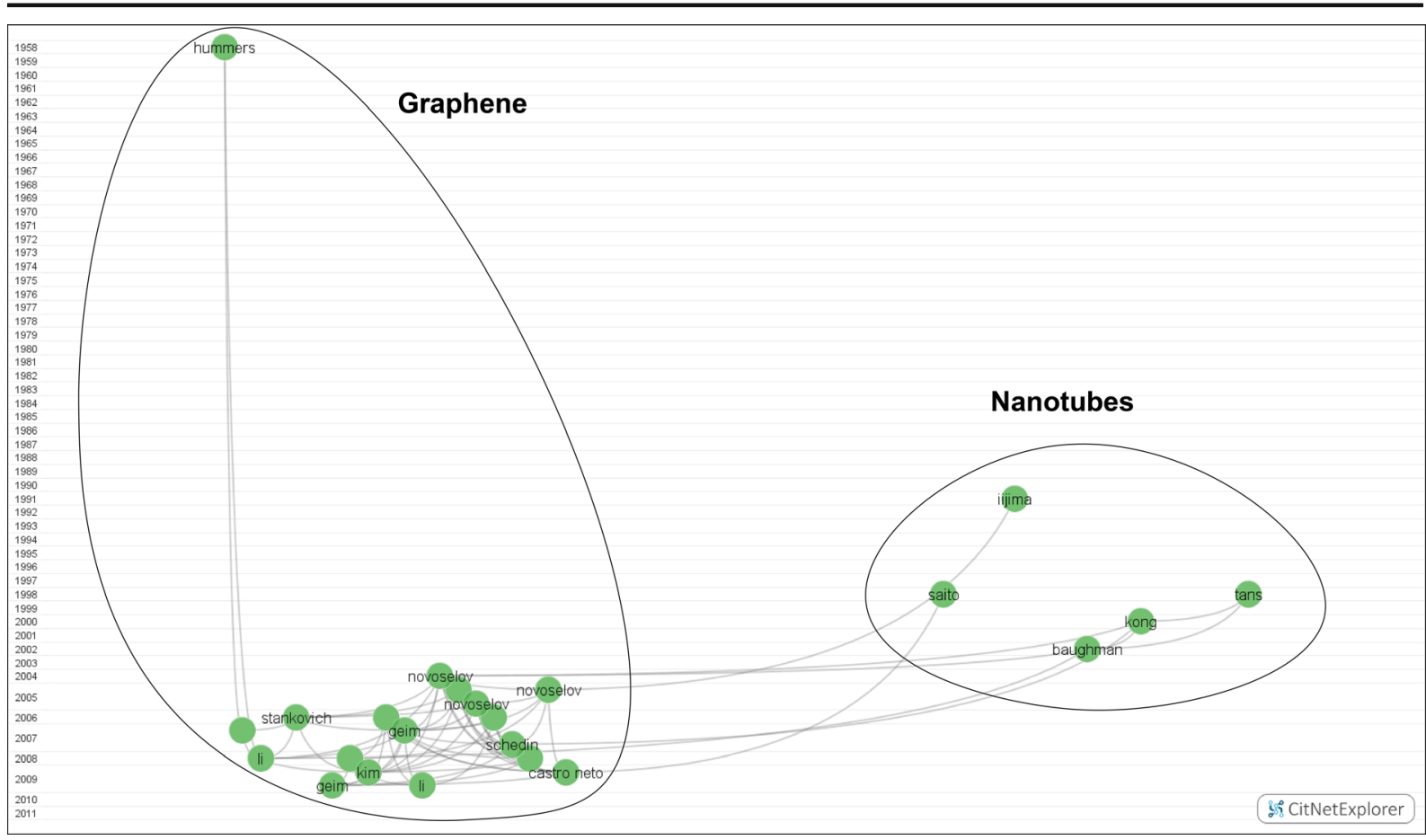

Fig. 6 Carbon nanomaterials. Available in high resolution at: http://www.ugr.es/local/benjamin/maps/Figure-6.png

to 30 or even to 50 terms, there are repetitions - even though the order of occurrence varies. This is an indication that the evolution of NST research is quite rapid, and the research lines tend to change as new advances are made (Tables 7 and 8).

Optics and Electronics (yellow cluster)

In most of the maps, this cluster occupied a central position, connected with the other clusters, a stem of sorts for the development of the NST network. Optics and Electronics provide foundations for chemical applications and for Biomedicine.

In the first period (2000-2003), Optics and Electronics appears closely linked in its upper sector to Microelectronics engineering and top-down processes and in its lower part to Synthesis of nanomaterials and bottomup processes.

The following period (2004-2007) shows how this cluster begins to gain strength and influence in the rest

Table 1 Science maps NST

\begin{tabular}{|c|c|c|c|}
\hline $\begin{array}{l}{ }^{{ }^{a}} \text { Science map } \\
\text { NST 2000-2003 } \\
(6,189 \text { items })\end{array}$ & $\begin{array}{l}{ }^{\mathrm{b}} \text { Science } \\
\text { map NST 2004-2007 } \\
(14,316 \text { items })\end{array}$ & $\begin{array}{l}{ }^{\mathrm{C}} \text { Science } \\
\text { map NST 2008- } \\
2010(20,709 \text { items })\end{array}$ & $\begin{array}{l}{ }^{d} \text { Science } \\
\text { map NST 2011-2013 } \\
(30,137 \text { items })\end{array}$ \\
\hline in & $\frac{1}{1-2}$ & ons & \\
\hline
\end{tabular}


Table 2 Identified clusters between 2000 and 2013

\begin{tabular}{|c|c|c|c|}
\hline $2000-2003$ & 2004-2007 & 2008-2010 & 2011-2013 \\
\hline $\begin{array}{l}\text { Microelectronics engineering } \\
\text { and top-down processes }\end{array}$ & $\begin{array}{l}\text { Microelectronics engineering and top- } \\
\text { down processes }\end{array}$ & $\begin{array}{l}\text { Microelectronics engineering } \\
\text { and top-down processes }\end{array}$ & $\begin{array}{l}\text { Microelectronics engineering } \\
\text { and top-down } \\
\text { processes + Organic } \\
\text { electronics }\end{array}$ \\
\hline $\begin{array}{l}\text { Synthesis of nanomaterials and } \\
\text { bottom-up } \\
\text { processes + Biotechnology } \\
\text { and Biomedicine }\end{array}$ & $\begin{array}{l}\text { Synthesis of nanomaterials and } \\
\text { bottom-up processes }\end{array}$ & $\begin{array}{l}\text { Synthesis of nanomaterials } \\
\text { and bottom-up } \\
\text { processes + Optics and } \\
\text { Electronics }\end{array}$ & $\begin{array}{l}\text { Synthesis of nanomaterials } \\
\text { and bottom-up } \\
\text { processes + Optics and } \\
\text { Electronics }\end{array}$ \\
\hline $\begin{array}{l}\text { Mechanical characteristics } \\
\text { of materials }\end{array}$ & $\begin{array}{l}\text { Mechanical characteristics of } \\
\text { materials }+ \text { Physical } \\
\text { characteristics of materials }\end{array}$ & $\begin{array}{l}\text { Mechanical characteristics of } \\
\text { materials }+ \text { Physical } \\
\text { characteristics of materials }\end{array}$ & $\begin{array}{l}\text { Mechanical characteristics } \\
\text { of materials }+ \text { Physical } \\
\text { characteristics of materials }\end{array}$ \\
\hline Optics and Electronics & Optics and Electronics & $\begin{array}{l}\text { Biotechnology and } \\
\text { Biomedicine: Biosensing }\end{array}$ & $\begin{array}{l}\text { Biotechnology and } \\
\text { Biomedicine: Biosensing }\end{array}$ \\
\hline $\begin{array}{l}\text { Physical characteristics } \\
\text { of materials }\end{array}$ & $\begin{array}{l}\text { Biotechnology and } \\
\text { Biomedicine }\end{array}$ & $\begin{array}{l}\text { Biotechnology and } \\
\text { Biomedicine: Therapeutic } \\
\text { biomedicine } \\
\text { Organic electronics }\end{array}$ & $\begin{array}{l}\text { Biotechnology and } \\
\text { Biomedicine: Therapeutic } \\
\text { biomedicine }\end{array}$ \\
\hline
\end{tabular}

Table 3 Most relevant terms of Optics and Electronics cluster

\begin{tabular}{|c|c|c|c|c|c|c|c|}
\hline $2000-2003$ & Score & 2004-2007 & Score & $\begin{array}{l}2008-2010 \\
\text { (joined SNBUP) }\end{array}$ & Score & $\begin{array}{l}2011-2013 \\
\text { (joined SNBUP) }\end{array}$ & Score \\
\hline External voltage & 7.00 & Nanoscale morphology & 16.58 & Electric vehicle & 11.16 & $\begin{array}{l}\text { Semiconductor } \\
\text { photocatalysis }\end{array}$ & 13.09 \\
\hline Lasing action & 5.59 & Charge collection & 15.00 & Pulverization & 9.64 & $\operatorname{MoSe} 2$ & 12.83 \\
\hline $\begin{array}{l}\text { Individual single walled } \\
\text { carbon nanotube }\end{array}$ & 5.32 & Improved performance & 11.29 & Graphite anode & 9.30 & $\mathrm{mAh} g 1$ & 9.79 \\
\hline Quantum rod & 4.55 & Polymer solar cell & 10.49 & Battery electrode & 9.16 & $\begin{array}{l}\text { Visible light photocatalytic } \\
\text { hydrogen }\end{array}$ & 8.98 \\
\hline Logic function & 4.29 & $\begin{array}{l}\text { Bulk heterojunction } \\
\text { solar cell }\end{array}$ & 10.04 & $\begin{array}{l}\text { Rechargeable } \\
\text { lithium battery }\end{array}$ & 8.53 & $\begin{array}{l}\text { Advanced electrode } \\
\text { material }\end{array}$ & 8.89 \\
\hline $\begin{array}{l}\text { Kilowatts per square } \\
\text { centimeter }\end{array}$ & 3.60 & Donor acceptor interface & 9.61 & Charge capacity & 8.13 & Robust adhesion & 8.42 \\
\hline $\begin{array}{l}\text { Electrical transport } \\
\text { measurement }\end{array}$ & 3.55 & Charge generation & 9.54 & Energy storage device & 7.48 & $\begin{array}{l}\text { Asymmetric } \\
\text { supercapacitor }\end{array}$ & 8.35 \\
\hline Transport study & 3.39 & Biological labeling & 9.12 & Cycle life & 7.41 & $\begin{array}{l}\text { Flexible energy storage } \\
\text { device }\end{array}$ & 8.21 \\
\hline Low temperature growth & 3.31 & Plastic solar cell & 8.30 & Fascinating property & 7.39 & Superior cyclability & 8.21 \\
\hline $\begin{array}{l}\text { Modules for experiments } \\
\text { in stellar astrophysics }\end{array}$ & 3.06 & Graphene nanoribbon & 8.05 & $\begin{array}{l}\text { Supercapacitor } \\
\text { electrode material }\end{array}$ & 7.09 & $\begin{array}{l}\text { High energy lithium } \\
\text { ion battery }\end{array}$ & 8.11 \\
\hline Density of states & 3.02 & $\begin{array}{l}\text { Poly3 hexylthiophene } \\
\text { butyric acid methyl ester }\end{array}$ & 7.95 & $\begin{array}{l}\text { High charge storage } \\
\text { capacity }\end{array}$ & 6.81 & $\begin{array}{l}\text { Capacitive energy } \\
\text { storage }\end{array}$ & 7.88 \\
\hline Laser emission & 3.02 & Semiconducting polymer & 7.94 & $\begin{array}{l}\text { Electrochemical } \\
\text { energy storage }\end{array}$ & 6.80 & New electrode material & 7.87 \\
\hline $\mathrm{CdSe}$ quantum dot & 2.80 & Solid state lighting & 7.69 & Hydrocarbon fuel & 6.77 & $\begin{array}{l}\text { Excellent mechanical } \\
\text { strength }\end{array}$ & 7.70 \\
\hline Dimensional plasmon & 2.77 & $\begin{array}{l}\text { Overall conversion } \\
\text { efficiency }\end{array}$ & 7.10 & Capacity fading & 6.75 & High performance libs & 7.66 \\
\hline Miniband transport & 2.77 & Multiple exciton generation & 7.06 & Gradual reduction & 6.64 & $\begin{array}{l}\text { Nanostructured electrode } \\
\text { material }\end{array}$ & 7.27 \\
\hline
\end{tabular}


Table 4 Most relevant terms of Synthesis of nanomaterials and bottom-up processes cluster

\begin{tabular}{|c|c|c|c|c|c|c|c|}
\hline $\begin{array}{l}2000-2003 \text { (Joined } \\
\text { Biotechnology and } \\
\text { Biomedicine) }\end{array}$ & Score & 2004-2007 & Score & $\begin{array}{l}\text { 2008-2010 (Joined } \\
\text { Optics and Electronics) }\end{array}$ & Score & $\begin{array}{l}2011-2013 \text { (Joined Optics } \\
\text { and Electronics) }\end{array}$ & Score \\
\hline $\mathrm{ZnO}$ nanowire & 20.81 & Nanometer wall thickness & 11.13 & Electric vehicle & 11.16 & Semiconductor photocatalysis & 13.09 \\
\hline Acid methyl ester & 16.34 & $\mathrm{Cd} 2$ ion & 9.85 & Pulverization & 9.64 & $\operatorname{MoSe} 2$ & 12.83 \\
\hline Sensitization & 16.28 & $\mathrm{TiO} 2$ nanotube array & 9.22 & Graphite anode & 9.30 & mAh g1 & 9.79 \\
\hline $\begin{array}{l}\text { Solar energy } \\
\text { conversion }\end{array}$ & 14.13 & Gold nanocage & 8.76 & Battery electrode & 9.16 & $\begin{array}{l}\text { Visible light photocatalytic } \\
\text { hydrogen }\end{array}$ & 8.98 \\
\hline Catalytic growth & 13.28 & Nanometer pore diameter & 8.76 & $\begin{array}{l}\text { Rechargeable lithium } \\
\text { battery }\end{array}$ & 8.53 & Advanced electrode material & 8.89 \\
\hline $\begin{array}{l}\text { Butyric acid methyl } \\
\text { ester }\end{array}$ & 12.95 & Silver nanocube & 8.47 & Charge capacity & 8.13 & Robust adhesion & 8.42 \\
\hline Shell thickness & 12.77 & Polyaniline nanofiber & 8.31 & Energy storage device & 7.48 & Asymmetric supercapacitor & 8.35 \\
\hline Core shell particle & 9.93 & Potentiostatic anodization & 8.21 & Cycle life & 7.41 & Flexible energy storage device & 8.21 \\
\hline $\mathrm{ZnO}$ nanorod & 9.83 & Photoanode & 7.42 & Fascinating property & 7.39 & Superior cyclability & 8.21 \\
\hline Electrospinning & 9.55 & Liberation & 7.15 & $\begin{array}{l}\text { Supercapacitor electrode } \\
\text { material }\end{array}$ & 7.09 & $\begin{array}{l}\text { High energy lithium ion } \\
\text { battery }\end{array}$ & 8.11 \\
\hline Nanobelt & 8.93 & Titania nanotube array & 6.80 & $\begin{array}{l}\text { High charge storage } \\
\text { capacity }\end{array}$ & 6.81 & Capacitive energy storage & 7.88 \\
\hline Silver nanowire & 8.81 & Block truncation coding & 6.79 & $\begin{array}{l}\text { Electrochemical energy } \\
\text { storage }\end{array}$ & 6.80 & New electrode material & 7.87 \\
\hline Novel nanostructure & 8.81 & Chemical activity & 6.46 & Hydrocarbon fuel & 6.77 & Excellent mechanical strength & 7.70 \\
\hline Soil & 8.59 & $\begin{array}{l}\text { Lithium ion secondary } \\
\text { battery }\end{array}$ & 6.23 & Capacity fading & 6.75 & High performance libs & 7.66 \\
\hline Polyfluorene & 8.42 & Same chemical composition & 6.16 & Gradual reduction & 6.64 & $\begin{array}{l}\text { Nanostructured electrode } \\
\text { material }\end{array}$ & 7.27 \\
\hline
\end{tabular}

of the research lines, with great relevance for Synthesis of nanomaterials and bottom-up processes.

From 2008 to 2010, Optics and Electronics is absorbed by the cluster Synthesis of nanomaterials and bottom-up processes, forming a single cluster. This union is due to the application of bottom-up processes and chemicals within Optics and Electronics, for instance optic sensors. At the end of the second study period, in 2007, the application of optic sensors takes off, out of the laboratory and into applied science. After 2008, Optics and Electronics is seen to approach the clusters Synthesis of nanomaterials and bottom-up processes and Biotechnology and Biomedicine (Biosensing and Therapy). In 2007, optic devices began to be used in biotechnology and medicine. At the same time, the nature of the material underwent development, first with inorganic and then with organic materials. For this reason, the term "quantum dot" disappears after 2008 and gives way to the entry of "graphene."

The final period studied (2011-2013) continues to show a union of clusters Optics and Electronics and
Synthesis of nanomaterials and bottom-up processes and suggests that these areas are bound to develop in tandem or even mutual dependence, eventually becoming one area.

Synthesis of nanomaterials and bottom-up processes (green cluster)

The cluster Synthesis of nanomaterials and bottomup processes appears closely tied to the cluster Optics and Electronics because in NST, the bottom-up materials are widely studied for optical applications. These are in turn used in sensors for biodetection and for the treatment of disease (Biomedicine).

Like the cluster Optics and Electronics, this one first involves inorganic materials but then progresses toward the almost exclusive use of organic materials by 2009 .

From 2000 to 2003, this cluster is fused to the cluster Biotechnology and Biomedicine. However, from 2004 to 2007 , they separate, giving rise to two distinctive neighboring clusters. It was in this period when the nucleus of optic sensors underwent development. In the period of 2008-2010, this cluster appears linked to Optics and 


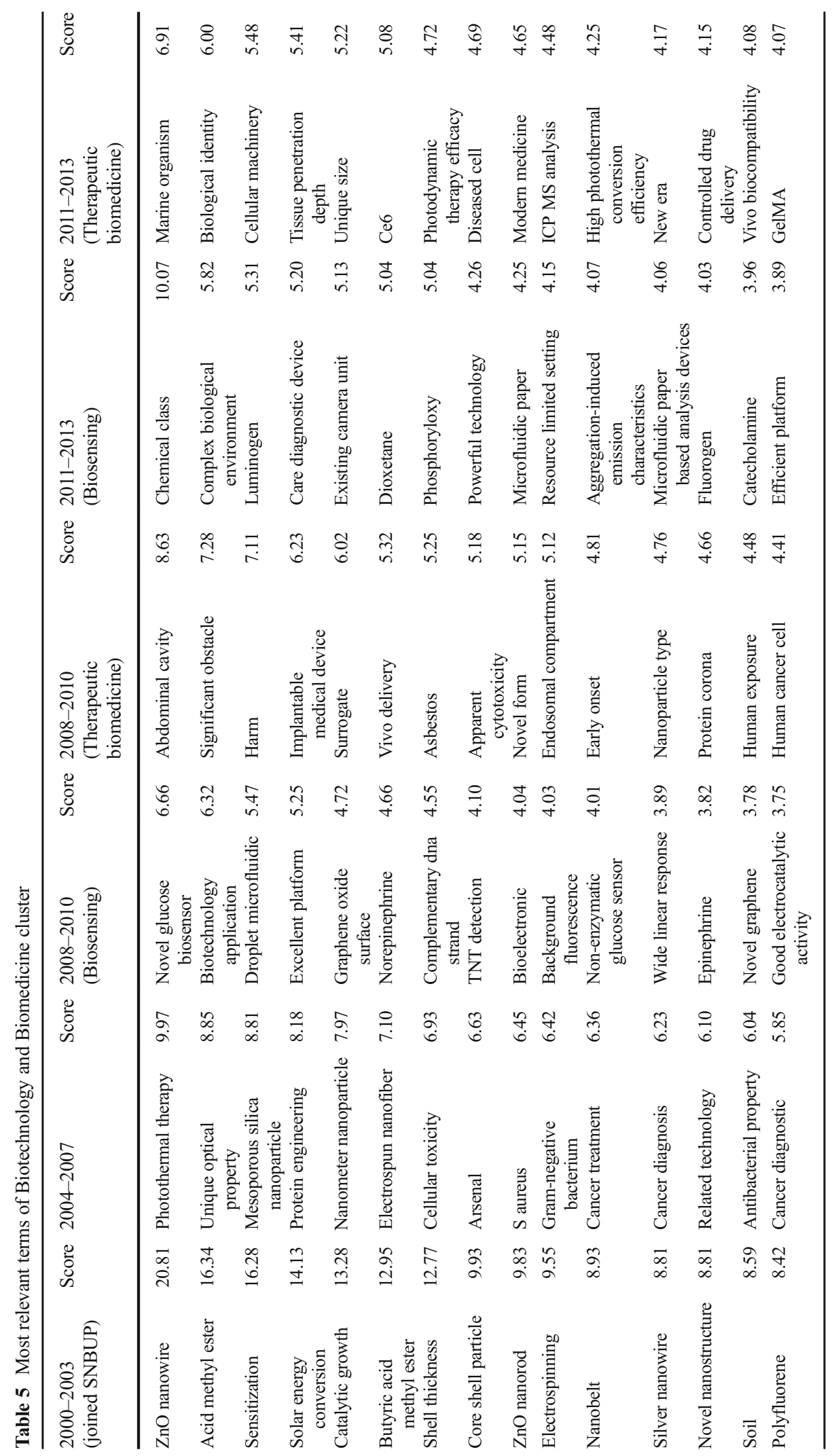


Table 6 Most relevant terms of Microelectronics engineering and top-down processes cluster

\begin{tabular}{|c|c|c|c|c|c|c|c|}
\hline $2000-2003$ & Score & 2004-2007 & Score & $2008-2010$ & Score & $2011-2013$ & Score \\
\hline Organic thin film transistor & 11.50 & Hydrophilic polymer & 7.36 & $\begin{array}{l}\text { Few layer graphene } \\
\text { films }\end{array}$ & 16.71 & Rich physic & 16.04 \\
\hline Non-volatile memory & 8.60 & Novel nanoscale & 7.17 & $\begin{array}{l}\text { Transparent } \\
\text { conducting film }\end{array}$ & 15.10 & WSe2 & 12.19 \\
\hline Optical application & 7.43 & Superhydrophilicity & 5.95 & Exciting potential & 13.48 & PTB7 & 11.65 \\
\hline Design consideration & 5.52 & New architecture & 5.66 & Scalable technique & 13.45 & MoS2 monolayer & 11.02 \\
\hline Ferroelectricity & 5.36 & Microscale device & 5.36 & Graphene electrode & 12.58 & Bilayer MoS2 & 10.10 \\
\hline Optical switch & 4.95 & $\begin{array}{l}\text { Superhydrophobic } \\
\text { coating }\end{array}$ & 5.12 & $\begin{array}{l}\text { Nitrogen-doped } \\
\text { graphene }\end{array}$ & 12.14 & Entire visible spectrum & 9.65 \\
\hline Luminescence efficiency & 4.20 & High gain & 4.94 & Arbitrary substrates & 11.20 & Standard AM & 9.47 \\
\hline Molecular monolayer & 3.78 & Superhydrophobicity & 4.75 & Large-scale growth & 10.99 & MoS2 transistor & 9.08 \\
\hline Alkyl & 3.71 & Further optimization & 4.57 & $\begin{array}{l}\text { Liquid phase } \\
\text { exfoliation }\end{array}$ & 10.80 & Ionic motion & 8.71 \\
\hline Energy consumption & 3.61 & $\begin{array}{l}\text { Optical coherence } \\
\text { tomography }\end{array}$ & 4.19 & $\begin{array}{l}\text { Individual graphene } \\
\text { sheet }\end{array}$ & 10.62 & Terminology & 8.57 \\
\hline $\begin{array}{l}\text { Carbon nanotube field effect } \\
\text { transistor }\end{array}$ & 3.44 & $\begin{array}{l}\text { Continuous flow } \\
\text { separation }\end{array}$ & 4.14 & Large area graphene & 10.18 & Efficiency limitation & 8.31 \\
\hline Strontium titanate & 3.36 & Enhanced mixing & 4.06 & $\begin{array}{l}\text { Optoelectronic } \\
\text { property }\end{array}$ & 10.02 & Valley polarization & 8.14 \\
\hline $\begin{array}{l}\text { Atomic force microscopy } \\
\text { cantilever }\end{array}$ & 3.34 & Crust & 4.03 & Thick sheet & 9.17 & $\begin{array}{l}\text { Efficient polymer solar } \\
\text { cell }\end{array}$ & 8.03 \\
\hline Conductive substrate & 3.19 & Bath temperature & 3.99 & Graphene oxide film & 9.04 & $\begin{array}{l}\text { Reduced charge } \\
\text { recombination }\end{array}$ & 7.92 \\
\hline Charge fluctuation & 2.97 & Lithographic approach & 3.85 & Single sheet & 8.93 & PEC water splitting & 7.80 \\
\hline
\end{tabular}

Electronics. Meanwhile, one sees that this cluster begins to interact with the cluster Microelectronics engineering and top-down processes, and we begin to see terms indicating the real applications of the top-down nanomaterials (microfluid, microchip, microchannel). At the same time, biosensors begin to be applied, namely, in 2008. In 2009, biosensors were introduced in microfluid devices and there was an explosion of output in biomedicine; hence, a new line of research appears. During the final interval of study (2011-2013), we find a new cluster next to this one, representing work with organic materials (Organic electronics).

Biotechnology and Biomedicine (purple and orange clusters)

The cluster Biotechnology and Biomedicine is linked to Synthesis of nanomaterials and bottom-up processes due to its use of this type of materials. It is also quite connected to Optics and Electronics because of optical measurements and to Microelectronics engineering and top-down processes because such devices are used as systems of detection.

In the first period of study, this cluster is joined to Synthesis of nanomaterials and bottom-up processes, but in the period of 2004-2007, the two clusters divide into separate research lines. Then, in the following period, given the scientific advances in Optics and Electronics and the Synthesis of nanomaterials and bottomup processes, this cluster splits in two: Biosensing (purple cluster) and Therapeutic biomedicine (orange cluster). In more recent years (2011-2013), Biosensing has captured more research, possibly because it provides more direct benefits for society.

Microelectronics engineering and top-down processes (red cluster).

The cluster Microelectronics engineering and topdown processes begins as a line of research related purely with electronics, but later, it begins to incorporate microfluids, thus shifting nearer to the cluster of Biosensing.

In 2000-2003, this cluster was only near Optics and Electronics (upper left). In the following period studied, the cluster grew substantially in size and part of its research came to border on Biotechnology and Biomedicine and Physical and mechanical characteristics of materials.

In the final period of study (2011-2013), the left part of the cluster Microelectronics engineering and top- 
Table 7 Most relevant terms of Physical and mechanical characteristics of materials cluster

\begin{tabular}{|c|c|c|c|c|c|c|c|c|c|}
\hline $\begin{array}{l}2000-2003 \\
\text { (Mechanical) }\end{array}$ & Score & $\begin{array}{l}\text { 2000-2003 } \\
\text { (Physical) }\end{array}$ & Score & 2004-2007 & Score & 2008-2010 & Score & 2011-2013 & Score \\
\hline Solid oxide fuel cell & 5.11 & Magnesium alloy AZ31 & 5.66 & $\begin{array}{l}\text { Mechanical } \\
\text { reinforcement }\end{array}$ & 5.95 & Enhanced strength & 6.99 & Local property & 5.76 \\
\hline Stage process & 3.66 & $\begin{array}{l}\text { Continuous dynamic } \\
\text { recrystallization }\end{array}$ & 3.96 & $\begin{array}{l}\text { Simultaneous } \\
\text { increase }\end{array}$ & 5.07 & $\begin{array}{l}\text { Effective } \\
\quad \text { reinforcement }\end{array}$ & 3.74 & $\begin{array}{l}\text { Video } \\
\text { recording }\end{array}$ & 5.20 \\
\hline High capacity & 3.54 & Ultrafine grained & 3.94 & Annealing time $\mathrm{t}$ & 3.24 & $\begin{array}{l}\text { Watt per meter } \\
\text { Kelvin }\end{array}$ & 2.92 & $\begin{array}{l}\text { Strong size } \\
\text { dependence }\end{array}$ & 3.73 \\
\hline Spark plasma & 3.52 & $\begin{array}{l}\text { Accumulative roll } \\
\text { bonding }\end{array}$ & 3.08 & Filler material & 2.98 & $\begin{array}{l}\text { Dimensional finite } \\
\text { element } \\
\text { simulation }\end{array}$ & 2.84 & Tafel analysis & 3.09 \\
\hline $\begin{array}{l}\text { High temperature } \\
\text { stability }\end{array}$ & 3.24 & Peak value & 2.96 & $\begin{array}{l}\text { Nanotube polymer } \\
\text { composite }\end{array}$ & 2.84 & Concrete & 2.54 & $\begin{array}{l}\text { Random } \\
\text { texture }\end{array}$ & 2.57 \\
\hline $\begin{array}{l}\text { Hall petch } \\
\quad \text { relationship }\end{array}$ & 3.21 & Nanocrystalline metal & 2.69 & MHz range & 2.59 & Ultimate strength & 2.50 & Si particle & 2.45 \\
\hline Yttrium oxide & 3.17 & $\begin{array}{l}\text { Recrystallization } \\
\text { mechanism }\end{array}$ & 2.46 & Ultrafine grain size & 2.54 & $\begin{array}{l}\text { Macromolecular } \\
\text { structure }\end{array}$ & 2.47 & $\begin{array}{l}\text { Relevant } \\
\text { temperature } \\
\text { range }\end{array}$ & 2.31 \\
\hline $\begin{array}{l}\text { Columnar grain } \\
\text { structure }\end{array}$ & 3.03 & Flow instability & 2.45 & Low ductility & 2.41 & Disclination & 2.18 & $\begin{array}{l}\text { Optimum } \\
\text { balance }\end{array}$ & 2.25 \\
\hline Coating property & 3.02 & $\begin{array}{l}\text { Continuous } \\
\text { recrystallization }\end{array}$ & 2.43 & $\begin{array}{r}\text { Good electrical } \\
\text { conductivity }\end{array}$ & 2.40 & Large strain & 2.09 & Primary focus & 2.20 \\
\hline Coating stir weld & 2.97 & Route c & 2.43 & $\begin{array}{l}\text { Ultrafine grained } \\
\text { microstructure }\end{array}$ & 2.38 & Damaged region & 2.09 & $\begin{array}{l}\text { Outstanding } \\
\text { mechanical } \\
\text { property }\end{array}$ & 2.16 \\
\hline Solid matrix & 2.97 & High pressure torsion & 2.39 & Inducing & 2.31 & Minimally & 2.07 & $\begin{array}{c}\text { Segregation } \\
\text { behavior }\end{array}$ & 2.16 \\
\hline $\begin{array}{l}\text { Multicomponent } \\
\text { system }\end{array}$ & 2.92 & $\begin{array}{l}\text { Equal channel angular } \\
\text { pressing }\end{array}$ & 2.34 & $\begin{array}{l}\text { Surface mechanical } \\
\text { attrition treatment }\end{array}$ & 2.29 & Major mechanism & 2.04 & Thick sheet & 2.10 \\
\hline Fold symmetry & 2.90 & Silicon nanotube & 2.31 & Microwave sintering & 2.25 & Extrusion texture & 2.02 & Multistep & 2.08 \\
\hline Load transfer & 2.86 & $\begin{array}{l}\text { Hot deformation } \\
\text { behavior }\end{array}$ & 2.30 & Deformability & 2.20 & Crystal form & 1.86 & LMC & 1.99 \\
\hline Automotive industry & 2.85 & Grain size dependence & 2.19 & Rapid heating & 2.08 & $\begin{array}{l}\text { Higher yield } \\
\text { strength }\end{array}$ & 1.86 & Cyclic strain & 1.96 \\
\hline
\end{tabular}

down processes approaches Biosensing, as the terms represented here frequently refer to microfluids, commonly used for biodetection. At the same time, this cluster becomes less compact, opening toward the right until it is situated parallel to the cluster Synthesis of nanomaterials and bottom-up processes, thereby demonstrating its influence in the rest of the disciplines within NST.

\section{Physical and mechanical characteristics of materials} (blue and pink clusters)

The cluster Physical and mechanical characteristics of materials could be considered the first research line to be developed in the field of NST. The studies along this line are related with the principals of physics and the study of the mechanical properties or physical characterizations of certain materials in conjunction with NST discoveries. Once these materials were more familiar at the nanometric scale, the line of research slowed down, while other lines began to evolve thanks to the discoveries recently made. Hence, the lines are seen to intersect or interact to some degree. The tendency over the years is for the cluster Physical and mechanical characteristics of materials to move away from the rest, although it still shares limited activity with Optics and Electronics, Synthesis of nanomaterials and bottom-up processes, and Microelectronics engineering and top-down processes. The interaction can be traced to the employment of materials common to all the clusters, yet the part dedicated to the study of mechanical properties of materials tends toward isolation.

During the period of 2000-2003, this cluster lies at a great distance from the other research lines. Another singular aspect of this cluster is its division into two lines. Namely, Physical characteristics of materials (pink cluster, top left) and Mechanical characteristics of materials (blue cluster, lower left). We also see a 
Table 8 Most relevant terms of Organic electronics cluster

\begin{tabular}{lr}
\hline 2008-2010 & Score \\
\hline Minority carrier diffusion length & 11.72 \\
Polymer donor & 8.27 \\
Vertical phase separation & 8.19 \\
High absorption coefficient & 7.87 \\
Fullerene acceptor & 7.61 \\
Polymer morphology & 6.14 \\
Solvent-free ionic liquid electrolyte & 5.98 \\
Reduced graphene oxide film & 5.97 \\
Photoconversion efficiency & 5.76 \\
Solution processed & 5.75 \\
Electron pathway & 5.72 \\
Functionalized graphene & 5.52 \\
Bulk heterojunction solar cell & 5.49 \\
Particulate film & 5.46 \\
Diketopyrrolopyrrole & 5.46 \\
\hline
\end{tabular}

distance from the other research lines identified. Yet, in the following period (2004-2007), the two lines fuse into a single cluster and remain attached until the end of the period.

Organic electronics (light blue cluster).

This cluster only appears in the period of 2008-2010, owing to the use of organic materials within the realm of NST research. This causes it to occupy a position nearby the cluster Synthesis of nanomaterials and bottom-up processes However, the line of research eventually disappears, absorbed into the cluster Microelectronic engineering and top-down processes during 2011-2013.

\section{Conclusions}

By means of CitnetExplorer, we have analyzed the intellectual structure of nanoscience and nanotechnology, identifying the seminal papers and key documents of all NST journals contained in the JCR Science Edition during the period 2000-2013.

In view of the influence that the most-cited works have exerted over the years studied, we conclude that seven groups can be discerned within the intellectual structure of NST. The articles making up these groupings are essential papers of reference for the development of the discipline, and they are recognized as such through citations by the community of scientists. The underlying structure visualized here shows that even a limited and recent time period serves to elaborate the genealogy of a field such as NST, as the scientific culture always leaves footprints behind - that is, new authors look to their predecessors for foundational knowledge (Bayer et al. 1990). Citation habits are strongly conditioned by the magnitude of scientific progress, as reflected by the articles by Iijima about carbon nanotubes, or the experiments of Novoselov and colleagues with graphene. Such crucial steps in the development of NST give rise to new subject areas that are eventually consolidated through an array of articles, either within or surrounding the intellectual sphere of Carbon nanomaterials.

Deserving mention as an outstanding example is the appearance of a thematic area related with Organic electronics, in this case attracting little attention among the scientific community, with only one article in the map cluster.

In our opinion, the structures identified and displayed in this work make manifest certain consolidated subject areas, stemming from works that report authentic scientific breakthroughs or key methodological proposals. There is evident consensus regarding the significance and usefulness of such contributions to NST.

Many of the documents identified in this study differ from those described by Kostoff et al. (2006a, 2007a), who took into account the citation of the documents of all scientific fields. Our work resorted to citation of the documents in the category NST of the WoS, meaning that we only accounted for citation by experts in the discipline. Visualization techniques and co-word analysis, in this case from titles and abstracts, allowed us to identify and project the evolution of the main research lines developed in NST from 2000 up to 2013.

The research lines traced are evidence of output exploring the behavior and phenomena at the nanoscale, together with the creation of new materials and their diverse applications. The profile of NST, accordingly, can be summed up as a young discipline in steady expansion, still needing some time to secure its foundations. This would explain why research lines such as Optics and Electronics, Synthesis of nanomaterials and bottom-up processes, or Physical and mechanical characteristics of materials maintain a constant flow of output. In contrast, Biotechnology and Biomedicine and Microelectronics engineering and top-down processes undergo a bit of a boom, perhaps because there are greater health-related social benefits associated with 
these topics. It could also be that these lines will produce important economic benefits in the near future. New research lines arise with the applications of nanomaterials together with the trend of working with organic materials, as seen in the case of Organic electronics. However, no research line related with NST toxicology in biological or environmental contexts was detected. Many words related to this field - nanoparticle toxicity, nanotoxicity, ecotoxicity, and so on-are included in the clusters Biotechnology and Biomedicine: Biosensing and Therapeutic biomedicine. This line will no doubt emerge and gain strength in the coming years, with new developments to generate methods for the safe production, use, and elimination of nanomaterials ( $\mathrm{Nel}$ et al. 2006).

When the number of documents published in a given research area is lower than in others, the number of citation is understandably low as well. Here, we could evoke the case of nanotoxicity. While some National Science Foundation (NSF) funded centers investigate the toxicity of nanomaterials (e.g., the Center for the Environmental Implication of Nanotechnology, Center for Sustainable Nanotechnology), overall, the production of scientific literature in this area that does not strictly correspond to Biotechnology and Biomedicine or Synthesis of nanomaterials and bottom-up processes may be low because its scope of action is limited. It may also be that scientific production in this specific realm is not registered in the leading multidisciplinary database of WoS. We might therefore affirm that our work has not yet come to an end along this research line: one of the journals that our search strategy includes is Nanotoxicology, a specialized journal in this field. On the other hand, one journal is not enough to provide insightful clues into a field of knowledge. On a broader panorama, as the science maps show, all the terms associated with nanotoxicity appear inside the clusters Biotechnology and Biomedicine or Synthesis of nanomaterials and bottom-up processes, not as a separate research line.

The lack of scientific literature in the wake of certain research lines and the low citation rate harvested by them could explain why most seminal papers identified in this manuscript pertain to the field of technology development.

Both the intellectual and the cognitive structures identified illustrate how NST continues to occupy a largely interdisciplinary scientific area. Indeed, its development depends on the knowledge that comes from physics, chemistry, and materials science, as displayed by the science maps. This is no novelty, having been endorsed by previous analyses (Meyer and Persson 1998; Schummer 2004; Porter and Youtie 2009; Jo et al. 2016), which to some extent demonstrate the convergence and validity of the scientometric methodology used in this study. In short, however, the present endeavor strives to trace the research lines of NST and thereby show how research in the area has changed over time. It is our hope that this study will become a useful tool of reference for the NST scientific community, revealing at a glance essential research lines in the light of landmark papers. Additionally, the methodology used in this study can be implemented in any other scientific field so as to explore its intellectual and cognitive structure.

Limitations and future efforts

We must acknowledge specific problems inherent to map elaboration. Firstly, when working with a free and non-controlled language for the titles and abstracts of the documents studied, there are inevitable problems of synonymy, acronymy, and plural vs. singular denoting a single concept. Secondly, the non-use of controlled language may have led to an absence of keywords that could define a research line quite well but were not included in the titles or abstracts that we worked with. A potential solution for the future is to use keyword authors and index keywords to create science maps. This would necessarily entail using both controlled and non-controlled language, because the use of controlled language alone implies an absence of terms presently used in NST (Braam et al. 1991b).

Another limitation is related to the specific knowledge of the studied subject (NST) that will be covered in future works. No doubt consultation with experts in the scientific field would solve this limitation, since the opinion, review, and comments from them would allow us to guarantee the results, as well as reinforce, reorganize, reclassify, and deepen the thematic specialization, and therefore delimit in a clearer and more concise way the groups pertaining to the network and co-word maps.

Looking once again toward the future, we believe that the design of search strategies will be improved, embracing journals that cover all the research lines that NST touches upon and not merely the journal set ascribed under WoS. Furthermore, the methodology put forth here may be exported to study the category NST in 
other databases of a multidisciplinary character, where this category has been previously identified. It could also be extrapolated to other thematic fields. In addition, overlay techniques may be used in conjunction with the method. To a certain extent, the future of bibliometric techniques for scientific categorization and exploration may be foreseen through similar efforts.

Acknowledgements The authors wish to thank the reviewers who have contributed significantly to improve the content of the original manuscript, Jean Sanders for translating/editing the manuscript, and Jorge F. Fernández Sánchez (associated professor at the University of Granada, Faculty of Science, Department of Analytical Chemistry) who helped as an expert in labeling the clusters to the science maps. Financial support from the Spanish National R\&D Plan is also acknowledged.

Funding This study was funded by the Ministerio de Economía y Competitividad of Spain through the State Programm of Research, Development and Innovation oriented to the Challenges of the Society [NANOMETRICS, CSO2014-57770-R)].

Compliance with ethical standards

Conflict of interest The authors declare that they have no conflict of interest.

\section{Appendix A. Abbreviated journal titles (JCR) query}

$\mathrm{SO}=($ ACM J EMERG TECH COM OR ACS APPL MATER INTER OR ACS NANO OR ADV FUNCT MATER OR ADV MATER OR AIP ADV OR BEILSTEIN J NANOTECH OR BIOMED MICRODEVICES OR BIOMICROFLUIDICS OR BIOSENS BIOELECTRON OR CURR NANOSCI OR DIG J NANOMATER BIOS OR FULLER NANOTUB CAR N OR IEEE T NANOBIOSCI OR I E E E T N A NOTECHNOL OR IE T NANOBIOTECHNOL OR INT J NANOMED OR INT J NANOTECHNOL OR J BIOMED NANOTECHNOL OR J COMPUT THEOR NANOS OR J EXP NANOSCI OR J LASER MICRO NANOEN OR J MICRO-NANOLITH MEM OR J MICROMECH MICROENG OR J NANO RES-SW OR J NANOBIOTECHNOL OR J NANOELECTRON OPTOE OR J NANOMATER OR J NANOPART RES OR J NANOPHOTONICS OR J NANOSCI NANOTECHNO OR J PHYS CHEM C OR J PHYS CHEM LETT OR J VAC SCI TECHNOL B OR LAB CHIP OR MAT SCI ENG A-STRUCT OR MATER EXPRESS OR MICRO NANO LETT OR
MICROELECTRON ENG OR MICROELECTRON J OR MICROELECTRON RELIAB OR MICROFLUID NANOFLUID OR MICROMACHINES-BASEL OR MICROPOR MESOPOR MAT OR MICROSYST TECHNOL OR NANO OR NANO ENERGY OR NANO LETT OR NANO RES OR NANO TODAY OR NANO-MICRO LETT OR NANOMATER NANOTECHNO OR NANOMED-NANOTECHNOL OR NANOMEDICINE-UK OR NANOSC MICROSC THERM OR NANOSCALE OR NANOSCALE RES LETT OR NANOSCI NANOTECH LET OR NANOTECHNOLOGY OR NANOTOXICOLOGY OR NAT NANOTECHNOL OR PART PART SYST CHAR OR PHOTONIC NANOSTRUCT OR PHYSICA E OR PLASMONICS OR PRECIS ENG OR RECENT PAT NANOTECH OR REV ADV MATER SCI OR SCI ADV MATER OR SCRIPTA MATER OR SMALL OR SYNTH REACT INORG M OR WIRES NANOMED NANOBI)

\section{Appendix B. Nodes and citations}

\begin{tabular}{|c|c|c|c|}
\hline Node & Year & Source & Citation \\
\hline Iijima & 1991 & Nature & 3183 \\
\hline Perdew & 1996 & Physical Review Letters & 3072 \\
\hline Novoselov & 2004 & Science & 2856 \\
\hline Geim & 2007 & Nature Materials & 2169 \\
\hline Kresse & 1996 & Physical Review B & 1997 \\
\hline Oregan & 1991 & Nature & 1779 \\
\hline Xia & 2003 & Advanced Materials & 1531 \\
\hline Kresse & 1999 & Physical Review B & 1529 \\
\hline Frisch & 2004 & Gaussian 03 Revision & 1492 \\
\hline Kresse & 1996 & Computational Materials Science & 1462 \\
\hline Huang & 2001 & Science & 1444 \\
\hline Monkhorst & 1976 & Physical Review B & 1441 \\
\hline Blochl & 1994 & Physical Review B & 1438 \\
\hline Kresge & 1992 & Nature & 1343 \\
\hline Alivisatos & 1996 & Science & 1311 \\
\hline Daniel & 2004 & Chemical Reviews & 1258 \\
\hline Novoselov & 2005 & Nature & 1201 \\
\hline Baughman & 2002 & Science & 1197 \\
\hline Lee & 1988 & Physical Review B & 1196 \\
\hline Becke & 1993 & Journal of Chemical Physics & 1172 \\
\hline Hummers & 1958 & $\begin{array}{l}\text { Journal of the American } \\
\text { Chemical Society }\end{array}$ & 1135 \\
\hline Murray & 1993 & $\begin{array}{l}\text { Journal of the American } \\
\text { Chemical Society }\end{array}$ & 1077 \\
\hline Johnson & 1972 & Physical Review B & 1075 \\
\hline
\end{tabular}




\begin{tabular}{|c|c|c|c|c|c|c|c|}
\hline Cui & 2001 & Science & 1063 & Novoselov & 2005 & PNAS & 659 \\
\hline Pan & 2001 & Science & 1041 & Schedin & 2007 & Nature Materials & 634 \\
\hline Wagner & 1964 & Applied Physics Letters & 1029 & $\mathrm{Yu}$ & 2003 & Chemistry of Materials & 633 \\
\hline Nie & 1997 & Science & 1029 & Bard & 2001 & Electrochemical Meth & 632 \\
\hline Kresse & 1993 & Physical Review B & 1026 & Berger & 2006 & Science & 629 \\
\hline Zhang & 2005 & Nature & 1026 & Kresse & 1994 & Physical Review B & 628 \\
\hline Sze & 1981 & Phys Semiconductor Devices & 1010 & Troullier & 1991 & Physical Review B & 621 \\
\hline Chan & 1998 & Science & 1001 & Bohren & 1983 & Absorption Scattering & 619 \\
\hline Bruchez & 1998 & Science & 996 & $\mathrm{Li}$ & 2008 & Science & 616 \\
\hline Kelly & 2003 & Journal of Physical Chemistry B & 992 & $\mathrm{Li}$ & 2005 & Nature Materials & 614 \\
\hline Zhao & 1998 & Science & 951 & Kneipp & 1997 & Physical Review Letters & 607 \\
\hline
\end{tabular}

Stankovich 2006 Nature 918

Fujishima 1972 Nature $\quad 913$

Kim 2009 Nature 903

Gratzel 2001 Nature 890

Li 2009 Science $\quad 889$

Michalet 2005 Science 876

Ferrari 2006 Physical Review Letters $\quad 875$

Kong 2000 Science 870

Perdew 1992 Physical Review B 861

Hoffmann 1995 Chemical Reviews 845

Vanderbilt 1990 Physical Review B 844

Burda 2005 Chemical Reviews 841

Beck 1992 Journal of the American 827

Lee 2008 Science 825

Perdew 1992 Physical Review B 818

Decher 1997 Science 799

Tans 1998 Nature 786

Castro Neto 2009 Reviews of Modern Physics 786

Morales 1998 Science 780

$\begin{array}{lll}\text { Huynh } & 2002 \text { Science } & 777\end{array}$

Saito $\quad 1998$ Phys Properties Carb 759

Geim 2009 Science 750

Kohn $\quad 1965$ Physical Review $\quad 736$

Wang 2006 Science 724

Li 2008 Nature Nanotechnology 724

$\begin{array}{lll}\text { Stankovich } 2007 \text { Carbon } & 719\end{array}$

Kreibig 1995 Optical Properties M 713

$\begin{array}{lll}\text { Frisch } & 2009 \text { Gaussian 09 Revision } & 708\end{array}$

Love $\quad 2005$ Chemical Reviews $\quad 702$

Asahi 2001 Science 700

Barnes 2003 Nature 697

Peng 2000 Nature 690

Soler 2002 Journal of Physics: $\quad 681$

Medintz 2005 Nature materials 672
Open Access This article is distributed under the terms of the Creative Commons Attribution 4.0 International License (http:// creativecommons.org/licenses/by/4.0/), which permits unrestricted use, distribution, and reproduction in any medium, provided you give appropriate credit to the original author(s) and the source, provide a link to the Creative Commons license, and indicate if changes were made.

\section{References}

Alivisatos AP (1996) Semiconductor clusters, nanocrystals, and quantum dots. Science 271(5251):933-937. doi:10.1126 /science.271.5251.933

Arencibia-Jorge R, Leydesdorff L, Chinchilla-Rodríguez Z, Rousseau R, Paris SW (2009) Retrieval of very large numbers of items in the web of science: an exercise to develop accurate search strategies. Prof Inform 18(5):529-533. doi:10.3145/epi.2009.sep.06

Arora SK, Porter AL, Youtie J, Shapira P (2013) Capturing new developments in an emerging technology: an updated search strategy for identifying nanotechnology research outputs. Scientometrics 95(1):351-370. doi:10.1007/s11192-0120903-6

Arora SK, Youtie J, Carley S, Porter AL, Shapira P (2014) Measuring the development of a common scientific lexicon in nanotechnology. J Nanopart Res 16(1):1-11. doi:10.1007 /s11051-013-2194-0

Asahi R, Morikawa T, Ohwaki T, Aoki K, Taga Y (2001) Visiblelight photocatalysis in nitrogen-doped titanium oxides. Science 293(5528):269-271. doi:10.1126/science.1061051

Bajwa RS, Yaldram K (2012) Research output in nanoscience and nanotechnology: Pakistan scenario. J Nanopart Res 14(2): 721. doi:10.1007/s11051-016-3473-3

Barcikowski S, Devesa F, Moldenhauer K (2009) Impact and structure of literature on nanoparticle generation by laser ablation in liquids. J Nanopart Res 11(8):1883-1893. doi:10.1007/s11051-009-9765-0

Baughman RH, Zakhidov AA, de Heer WA (2002) Carbon nanotubes - the route toward applications. Science 297(5582): 787-792. doi:10.1126/science.1060928

Bayer AE, Smart JC, McLaughlin GW (1990) Mapping intellectual structure of a scientific subfield through author 
cocitations. J Am Soc Inform Sci 41(6):444-452. doi:10.1002/(SICI)1097-4571(199009)41:6<444::AIDASI12>3.0.CO;2-J

Beck JS, Vartuli JC, Roth WJ, Leonowicz ME, Kresge CT, Schmitt KD, Chu CTW, Olson DH, Sheppard EW, McCullen SB, Higgins JB, Schlenker JL (1992) A new family of mesoporous molecular sieves prepared with liquid crystal templates. J Am Chem Soc 114(27):10834-10843. doi: $10.1021 / \mathrm{ja} 00053 \mathrm{a} 020$

Becke AD (1993) Density-functional thermochemistry. III The role of exact exchange. J Chem Phys 98(7):5648-5652. doi:10.1063/1.464913

Bellardo T (1980) The use of co-citations to study science. Libr Res, 1980-1981 2(3):231-237

Beumer K (2016) Broadening nanotechnology's impact on development. Nat Nanotech 11(5):398-400. doi:10.1038 /nnano.2016.71

Binnig G, Rohrer H (1983) Scanning tunneling microscopy. Surf Sci 126(1-3):236-244. doi:10.1016/0039-6028(83)90716-1

Blöchl PE (1994) Projector augmented-wave method. Phys Rev B 50(24):17953-17979. doi:10.1103/PhysRevB.50.17953

Bohren CF, Huffman DR (1983) Absorption and scattering of light by small particles. John Wiley \& Sons, Weinheim

Borgman C (1989) Bibliometrics and scholarly communication: editor's introduction. Commun Res 16(5):583-599. doi: $10.1177 / 009365089016005002$

Börner K, Chen C, Boyack KW (2003) Visualizing knowledge domains. Annu Rev Inform Sci 37(1):179-255. doi:10.1002 /aris.1440370106

Boyack KW, Börner K, Klavans R (2009) Mapping the structure and evolution of chemistry research. Scientometrics 79(1): 45-60. doi:10.1007/s11192-009-0403-5

Boyack KW, Klavans R, Börner K (2005) Mapping the backbone of science. Scientometrics 64(3):351-374. doi:10.1007 /s11192-005-0255-6

Braam RR, Moed HF, van Raan AFJ (1991a) Mapping of science by combined co-citation and word analysis. I. Structural aspects. J Am Soc Inform Sci 42(4):233-245. doi:10.1002/(SICI)10974571(199105)42:4<233::AID-ASI1>3.0.CO;2-I

Braam RR, Moed HF, van Raan AFJ (1991b) Mapping of science by combined co-citation and word analysis. II: dynamical aspects. J Am Soc Inform Sci 42(4):252-266. doi:10.1002/(SICI)10974571(199105)42:4<252::AID-ASI2>3.0.CO;2-G

Braun T, Schubert A, Zsindely S (1997) Nanoscience and nanotechnology on the balance. Scientometrics 38(2):321-325. doi:10.1007/BF02457417

Bruchez M, Moronne M, Gin P, Weiss S, Alivisatos AP (1998) Semiconductor nanocrystals as fluorescent biological labels. Science 281(5385):2013-2016. doi:10.1126 /science.281.5385.2013

Burda C, Chen X, Narayanan R, El-Sayed MA (2005) Chemistry and properties of nanocrystals of different shapes. Chem Rev 105(4):1025-1102. doi:10.1021/cr030063a

Cahlík T, Jiřina M (2006) Law of cumulative advantages in the evolution of scientific fields. Scientometrics 66(3):441-449. doi:10.1007/s11192-006-0032-1

Callon M, Courtial J, Laville F (1991) Co-word analysis as a tool for describing the network of interactions between basic and technological research: the case of polymer chemistry. Scientometrics 22(1):155-205. doi:10.1007/BF02019280
Callon M, Courtial JP, Turner WA, Bauin S (1983) From translations to problematic networks: an introduction to co-word analysis. Soc Sci Inform 22(2):191-235. doi:10.1177 /053901883022002003

Callon M, Law J, Rip A (eds) (1986) Mapping the dynamics of science and technology: sociology of science in the real world. Macmillan Press, London. doi:10.1007/978-1-34907408-2

Cantos-Mateos G, Vargas-Quesada B, Chinchilla-Rodríguez Z, Zulueta MA (2012) Stem cell research: bibliometric analysis of main research areas through KeyWords plus. ASLIB Proc 64(6):561-590. doi:10.1108/00012531211281698

Cantos-Mateos G, Zulueta-García MA, Vargas-Quesada B, Chinchilla-Rodríguez Z (2014) Estudio evolutivo de la investigación española con células madre. Visualización e identificación de las principales líneas de investigación. Prof Inform 23(3):259-271. doi:10.3145/epi.2014.may.06

Chan WC, Nie S (1998) Quantum dot bioconjugates for ultrasensitive nonisotopic detection. Science 281(5385):2016-2018. doi:10.1126/science.281.5385.2016

Chen C (1999) Visualizing semantic spaces and author co-citation networks in digital libraries. Inform Process Manag 35(3): 401-420. doi:10.1016/S0306-4573(98)00068-5

Chen H, Roco MC, Son J, Jiang S, Larson CA, Gao Q (2013) Global nanotechnology development from 1991 to 2012: patents, scientific publications, and effect of NSF funding. $J$ Nanopart Res 15(9):1951. doi:10.1007/s11051-013-1951-4

Chinchilla-Rodríguez Z, Ocaña-Rosa K, Vargas-Quesada B (2016a) How to combine research guarantor and collaboration patterns to measure scientific performance of countries in scientific fields: nanoscience and nanotechnology as a case study. Front Res Metr Anal 1:2. doi:10.3389 /frma.2016.00002

Chinchilla-Rodríguez Z, Miguel, S, Perianes-Rodríguez A, Ovalle-Perandones A, Olmeda-Gómez C (2016b) Autonomy vs. dependency of scientific collaboration in scientific performance. 21 st International Conference on Science and Technology Indicators, STI2016. Valencia, Spain, 14-16 Sept 2016

Cui Y, Wei Q, Park H, Lieber CM (2001) Nanowire nanosensors for highly sensitive and selective detection of biological and chemical species. Science 293(5533):1289-1292. doi:10.1126/science. 1062711

Daniel MC, Astruc D (2004) Gold nanoparticles: assembly, supramolecular chemistry, quantum-size-related properties, and applications toward biology, catalysis, and nanotechnology. Chem Rev 104(1):293-346. doi:10.1021/cr030698+

Decher G (1997) Fuzzy nanoassemblies: toward layered polymeric multicomposites. Science 277(5330):1232-1237. doi:10.1126/science.277.5330.1232

Ding Y, Chowdhury GG, Foo S (2001) Bibliometric cartography of information retrieval research by using co-word analysis. Inform Process Manag 37(6):817-842. doi:10.1016/S03064573(00)00051-0

Egghe L, Rousseau R (1990) Introduction to Informetrics: quantitative methods in library, documentation and information science. Elsevier Science Publishers, Amsterdam

Elsevier BV (2015) Scopus. www.scopus.com. Accessed 21 Jul 2015 
Feynman RP (1960) There's plenty of room at the bottom. An invitation to enter a new field of physics. Eng Sci 23(5):2236

Frisch MJ, Trucks GW, Schlegel HB, Scuseria GE, Robb MA, Cheeseman JR, Montgomery JA, Vreven T, Kudin $\mathrm{KN}$, Burant JC, Millam JM, Iyengar SS, Tomasi J, Barone V, Mennucci B, Cossi M, Scalmani G, Rega N, Petersson GA, Nakatsuji H, Hada M, Ehara M, Toyota K, Fukuda R, Hasegawa J, Ishida M, Nakajima T, Honda Y, Kitao O, Nakai H, Klene M, Li X, Knox JE, Hratchian HP, Cross JB, Bakken V, Adamo C, Jaramillo J, Gomperts R, Stratmann RE, Yazyev O, Austin AJ, Cammi R, Pomelli C, Ochterski JW, Ayala PY, Morokuma K, Voth GA, Salvador P, Dannenberg JJ, Zakrzewski VG, Dapprich S, Daniels AD, Strain MC, Farkas O, Malick DK, Rabuck AD, Raghavachari K, Foresman JB, Ortiz JV, Cui Q, Baboul AG, Clifford S, Cioslowski J, Stefanov BB, Liu G, Liashenko A, Piskorz P, Komaromi I, Martin RL, Fox DJ, Keith T, Al-Laham MA, Peng CY, Nanayakkara A, Challacombe M, Gill PMW, Johnson B, Chen W, Wong MW, Gonzalez C, Pople JA (2004) Gaussian 03, Revision C.02. Gaussian, Inc., Wallingford

Frisch MJ, Trucks GW, Schlegel HB, Scuseria GE, Robb MA, Cheeseman JR, Scalmani G, Barone V, Mennucci B, Petersson GA, Nakatsuji H, Caricato M, Li X, Hratchian HP, Izmaylov AF, Bloino J, Zheng G, Sonnenberg JL, Hada M, Ehara M, Toyota K, Fukuda R, Hasegawa J, Ishida M, Nakajima T, Honda Y, Kitao O, Nakai H, Vreven T, Montgomery JA, Peralta JE, Ogliaro F, Bearpark M, Heyd JJ, Brothers E, Kudin KN, Staroverov VN, Kobayashi R, Normand J, Raghavachari K, Rendell A, Burant JC, Iyengar SS, Tomasi J, Cossi M, Rega N, Millam JM, Klene M, Knox JE, Cross JB, Bakken V, Adamo C, Jaramillo J, Gomperts R, Stratmann RE, Yazyev O, Austin AJ, Cammi R, Pomelli C, Ochterski JW, Martin RL, Morokuma K, Zakrzewski VG, Voth GA, Salvador P, Dannenberg JJ, Dapprich S, Daniels AD, Farkas Ö, Foresman JB, Ortiz JV, Cioslowski J, Fox DJ (2009) Gaussian 09, Revision E.01. Gaussian, Inc., Wallingford

Fujishima A (1972) Electrochemical photolysis of water at a semiconductor electrode. Nature 238(5358):37-38. doi: $10.1038 / 238037 \mathrm{a} 0$

Garfield E (1972) Citation analysis as a tool in journal evaluation. Science 178(4060):471-479. doi:10.1126 /science.178.4060.471

Garfield E (1979) Citation indexing its theory and application in science, technology, and humanities. Wiley, New York

Garfield E (ed) (1980) SCI journal citation reports: a bibliometric analysis of science journals in the ISI data base, Science Citation Index 1979 Annual, 14. Institute for Scientific Information, Philadelphia

Garfield E (2004) Historiographic mapping of knowledge domains literature. J Inf Sci 30(2):119-145. doi:10.1177 /0165551504042802

Garfield E (2009) From the science of science to scientometrics visualizing the history of science with HistCite software. J Informetr 3(3):173-179. doi:10.1016/j.joi.2009.03.009

Garfield E, Pudovkin AI, Istomin VS (2003) Why do we need algorithmic historiography? J Am Soc Inf Tec 54(5):400412. doi:10.1002/asi.10226
Grätzel M (2001) Photoelectrochemical cells. Nature 414(6861): 338-344. doi:10.1038/35104607

Grieneisen ML (2010) The proliferation of nano journals. Nat Nanotechnol 5(12):825-825. doi:10.1038/nnano.2010.216

Grieneisen M, Zhang M (2011) Nanoscience and nanotechnology: evolving definitions and growing footprint on the scientific landscape. Small 7(20):2836-2839. doi:10.1002 /smll.201100387

Guan J, Liu N (2014) Measuring scientific research in emerging nano-energy field. J Nanopart Res 16(4):2356. doi:10.1007 /s11051-014-2356-8

He Q (1999) Knowledge discovery through co-word analysis. Libr Trends 48(1):133-159

Hicks D (1987) Limitations of co-citation analysis as a tool for science policy. Soc Stud Sci 17(2):295-316. doi:10.1177 /030631287017002004

Hoffmann MR, Martin ST, Choi W, Bahnemann DW (1995) Environmental applications of semiconductor photocatalysis. Chem Rev 95(1):69-96. doi:10.1021/cr00033a004

Hu G, Liu W (2015) Nano/micro-electro mechanical systems: a patent view. J Nanopart Res 17(12):465. doi:10.1007 /s11051-015-3273-1

Huang MH, Mao S, Feick H, Yan H, Wu Y, Kind H, Weber E, Russo R, Yang P (2001) Room-temperature ultraviolet nanowire nanolasers. Science 292(5523):1897-1899. doi:10.1126 /science.1060367

Huang Z, Chen H, Li X, Roco MC (2006) Connecting NSF funding to patent innovation in nanotechnology (20012004). J Nanopart Res 8(6):859-879. doi:10.1007/s11051006-9147-9

Huang C, Notten A, Rasters N (2011) Nanoscience and technology publications and patents: a review of social science studies and research strategies. J Technol Transfer 36(2): 145-172. doi:10.1007/s10961-009-9149-8

Hummers WS, Offeman RE (1958) Preparation of graphitic oxide. J Am Chem Soc 80(6):1339-1339. doi:10.1021/ja01539 a017

Huynh WU, Dittmer JJ, Alivisatos AP (2002) Hybrid nanorodpolymer solar cells. Science 295(5564):2425-2427. doi:10.1126/science.1069156

Iijima S (1991) Helical microtubules of graphitic carbon. Nature 354(6348):56-58. doi:10.1038/354056a0

Invernizzi N, Foladori G, Robles-Belmont E, Lau EZ, Figueroa EA, Bagattolli C, Carrozza TJ, Chiancone A, Urquijo W (2015) Nanotechnology for social needs: contributions from Latin American research in the areas of health, energy and water. J Nanopart Res 17(5):233. doi:10.1007/s11051-0153037-y

Jafari M, Zarghami HR (2016) Measuring nanotechnology development through the study of the dividing pattern between developed and developing countries during 2000-2014. J Nanopart Res 18(7):180. doi:10.1007/s11051-016-3431-0

Jo H, Park Y, Kim SE, Lee H (2016) Exploring the intellectual structure of nanoscience and nanotechnology: journal citation network analysis. J Nanopart Res 18:167. doi:10.1007 /s11051-016-3473-3

Johnson PB, Christy RW (1972) Optical constants of the noble metals. Phys Rev B 6(12):4370-4379. doi:10.1103 /PhysRevB.6.4370

Kelly KL, Coronado E, Zhao LL, Schatz GC (2003) The optical properties of metal nanoparticles: the influence of size, shape, 
and dielectric environment. J Phys Chem B 107(3):668-677. doi:10.1021/jp026731y

Kohn W, Sham LJ (1965) Self-consistent equations including exchange and correlation effects. Phys Rev 140(4A): A1133-A1138. doi:10.1103/PhysRev.140.A1133

Kong J, Franklin NR, Zhou C, Chapline MG, Peng S, Cho K, Dai $\mathrm{H}$ (2000) Nanotube molecular wires as chemical sensors. Science 287(5453):622-625. doi:10.1126 /science.287.5453.622

Kostoff RN, Shlesinger MF (2005) CAB: citation-assisted-background. Scientometrics 62(2):199-212. doi:10.1007/s11192005-0014-8

Kostoff RN, Murday JS, Lau CGY, Tolles WM (2006a) The seminal literature of nanotechnology research. J Nanopart Res 8(2):193-213. doi:10.1007/s11051-005-9034-9

Kostoff RN, Stump JA, Johnson D, Murday JS, Lau CGY, Tolles WM (2006b) The structure and infrastructure of the global nanotechnology literature. J Nanopart Res 8(3):301-321. doi:10.1007/s11051-005-9035-8

Kostoff RN, Koytcheff RG, Lau CGY (2007a) Technical structure of the global nanoscience and nanotechnology literature. J Nanopart Res 9(5):701-724. doi:10.1007/s11051-007-9224-8

Kostoff RN, Koytcheff RG, Lau CGY (2007b) Structure of the global nanoscience and nanotechnology research literature. DTIC Technical Report Number ADA461930, Defense Technical Information Center, Fort Belvoir, VA, http://www.dtic.mil/

Kostoff RN, Barth RB, Lau CGY (2008) Quality vs. quantity of publications in nanotechnology field from the People's Republic of China. Chinese Sci Bull 53(8):1272-1280. doi:10.1007/s11434-008-0183-y

Kreibig U, Vollmer M (1995) Optical properties of metal clusters. Springer, New York. doi:10.1007/978-3-662-09109-8

Kresge CT, Leonowicz ME, Roth WJ, Vartuli JC, Beck JS (1992) Ordered mesoporous molecular sieves synthesized by a liquid-crystal template mechanism. Nature 359(6397):710712. doi:10.1038/359710a0

Kresse G, Furthmüller J (1996a) Efficient iterative schemes for ab initio total-energy calculations using a plane-wave basis set. Phys Rev B 54(16):11169-11186. doi:10.1103 /PhysRevB.54.11169

Kresse G, Furthmüller J (1996b) Efficiency of ab-initio total energy calculations for metals and semiconductors using a plane-wave basis set. Comp Mater Sci 6(1):15-50. doi:10.1016/0927-0256(96)00008-0

Kresse G, Hafner J (1993) Ab initio molecular dynamics for liquid metals. Phys Rev B 47(1):558-561. doi:10.1103 /PhysRevB.47.558

Kresse G, Hafner J (1994) Ab initio molecular-dynamics simulation of the liquid-metal-amorphous-semiconductor transition in germanium. Phys Rev B 49(20):14251-14269. doi:10.1103/PhysRevB.49.14251

Kresse G, Joubert D (1999) From ultrasoft pseudopotentials to the projector augmented-wave method. Phys Rev B 59(3):17581775. doi:10.1103/PhysRevB.59.1758

Lau EZ, Frederick S, Foladori G (2014) Twelve years of nanoscience and nanotechnology publications in Mexico. J Nanopart Res 16(1):2193. doi:10.1007/s11051-013-2193-1

Lavrik OL, Busygina TV, Shaburova NN, Zibareva IV (2015) Nanoscience and nanotechnology in the Siberian Branch of the Russian Academy of Sciences: bibliometric analysis and evaluation. J Nanopart Res 17(2):90. doi:10.1007/s11051015-2900-1

Law M, Greene LE, Johnson JC, Saykally R, Yang P (2005) Nanowire dye-sensitized solar cells. Nat Mater 4(6):455459. doi:10.1038/nmat1387

Lawani SM (1980) Quality, collaboration, and citations in cancer research: a bibliometric study. $\mathrm{PhD}$ thesis, Florida State University, Tallahassee

Lawani SM (1981) Bibliometrics: its theoretical foundations, methods and applications. Libri 31(1):294-315. doi:10.1515/libr.1981.31.1.294

Lee WH (2008) How to identify emerging research fields using scientometrics: an example in the field of information security. Scientometrics 76(3):503-525. doi:10.1007/s11192007-1898-2

Lee C, Yang W, Parr RG (1988) Development of the Colle-Salvetti correlation-energy formula into a functional of the electron density. Phys Rev B 37(2):785-789. doi:10.1103 /PhysRevB.37.785

Leitch ME, Casman E, Lowry GVJ (2012) Nanotechnology patenting trends through an environmental lens: analysis of materials and applications. J Nanopart Res 14:1283. doi:10.1007/s11051-012-1283-9

Leydesdorff L (1987) Various methods for the mapping of science. Scientometrics 11(5-6):295-324. doi:10.1007/BF02279351

Leydesdorff L (1989) The relations between qualitative theory and scientometric methods in science and technology studies. Scientometrics 15(5-6):333-347. doi:10.1007/BF02017058

Leydesdorff L, Rafols I (2009) A global map of science based on the ISI subject categories. J Am Soc Inf Sci Tec 60(2):348362. doi:10.1002/asi.20967

Leydesdorff L, Rafols I (2011) Local emergence and global diffusion of research technologies: an exploration of patterns of network formation. J Am Soc Inf Sci Tec 62(5):846-860. doi:10.1002/asi.21509

Leydesdorff L, Moya-Anegón F, Guerrero-Bote VP (2010) Journal maps on the basis of Scopus data: a comparison with the journal citation reports of the ISI. J Am Soc Inf Sci Tec 61(2):352-369. doi:10.1002/asi.21250

Leydesdorff L, Moya-Anegón F, Guerrero-Bote VP (2015) Journal maps, interactive overlays, and the measurement of interdisciplinarity on the basis of Scopus data (1996-2012). J Assoc Inf Sci Tec 66(5):1001-1016. doi:10.1002/asi.23243

Li G, Shrotriya V, Huang J, Yao Y, Moriarty T, Emery K, Yang Y (2005) High-efficiency solution processable polymer photovoltaic cells by self-organization of polymer blends. Nat Mater 4(11):864-868. doi:10.1038/nmat1500

Li X, Chen H, Huang Z, Roco MC (2007) Patent citation network in nanotechnology (1976-2004). J Nanopart Res 9(3):337352. doi:10.1007/s11051-006-9194-2

Liu X, Zhang P, Li X, Chen H, Dang Y, Larson C, Roco MC, Wang X (2009) Trends for nanotechnology development in China, Russia, and India. J Nanopart Res 11(8):1845-1866. doi:10.1007/s11051-009-9698-7

Liu XJ, Zhang LA, Hong S (2011) Global biodiversity research during 1900-2009: a bibliometric analysis. Biodivers Conserv 20(4):807-826. doi:10.1007/s10531-010-9981-z

López Cadenas MS, Hasmy A, Vessuri H (2011) Nanoscience and nanotechnology in Venezuela. J Nanopart Res 13(8):31013106. doi:10.1007/s11051-011-0434-8 
Love JC, Estroff LA, Kriebel JK, Nuzzo RG, Whitesides GM (2005) Self-assembled monolayers of thiolates on metals as a form of nanotechnology. Chem Rev 105(4):1103-1170. doi:10.1021/cr0300789

Medintz IL, Uyeda HT, Goldman ER, Mattoussi H (2005) Quantum dot bioconjugates for imaging, labelling and sensing. Nat Mater 4(6):435-446. doi:10.1038/nmat1390

Menéndez-Manjón A, Moldenhauer K, Wagener P, Barcikowski S (2011) Nano-energy research trends: bibliometrical analysis of nanotechnology research in the energy sector. J Nanopart Res 13(9):3911-3922. doi:10.1007/s11051-011-0344-9

Meyer M, Persson O (1998) Nanotechnology-interdisciplinarity, patterns of collaboration and differences in application. Scientometrics 42(2):195-205. doi:10.1007/BF02458355

Michalet X, Pinaud FF, Bentolila LA, Tsay JM, Doose S, Li JJ, Sundaresan G, Wu AM, Gambhir SS, Weiss S (2005) Quantum dots for live cells, in vivo imaging, and diagnostics. Science 307(5709):538-544. doi:10.1126/science.1104274

Milojević S (2012) Multidisciplinary cognitive content of nanoscience and nanotechnology. J Nanopart Res 14(1): 685. doi:10.1007/s11051-011-0685-4

Morales AM, Lieber CM (1998) A laser ablation method for the synthesis of crystalline semiconductor nanowires. Science 279(5348):208-211. doi:10.1126/science.279.5348.208

Moya-Anegón F, Vargas-Quesada B, Herrero-Solana V, Chinchilla-Rodríguez Z, Corera-Álvarez E, MuñozFernández FJ (2004) A new technique for building maps of large scientific domains based on the cocitation of classes and categories. Scientometrics 61(1):129-145. doi:10.1023 /B:SCIE.0000037368.31217.34

Moya-Anegón F, Vargas-Quesada B, Corera-Álvarez E, MuñozFernández FJ, Herrero-Solana V, González-Molina A, Chinchilla-Rodríguez Z (2006) Visualización y análisis de la estructura científica española: ISI Web of Science 19902005. Prof Inform 15(4):258-269. doi:10.3145/epi.2006. jul.03

Moya-Anegón F, Vargas-Quesada B, Chinchilla-Rodríguez Z, Corera-Álvarez E, Muñoz-Fernández FJ, Herrero-Solana V (2007) Visualizing the marrow of science. J Am Soc Inf Sci Tec 58(14):2167-2179. doi:10.1002/asi.20683

Munoz-Sandoval E (2014) Trends in nanoscience, nanotechnology, and carbon nanotubes: a bibliometric approach. J Nanopart Res 16(1):1-22. doi:10.1007/s11051-013-2152-x

Murray C, Norris DJ, Bawendi MG (1993) Synthesis and characterization of nearly monodisperse $\mathrm{CdE}(\mathrm{E}=$ sulfur, selenium, tellurium) semiconductor nanocrystallites. J Am Chem Soc 115(19):8706-8715. doi:10.1021/ja00072a025

Narin F (1976) Evaluative bibliometrics: the use of publication and citation analysis in the evaluation of scientific activity. Contract report to the National Science Foundation. Computer Horizons, Washington DC

Neff MW, Corley EA (2009) 35 years and 160,000 articles: a bibliometric exploration of the evolution of ecology. Scientometrics 80(3):657-682. doi:10.1007/s11192-0082099-3

Nel A, Xia T, Mädler L, Li N (2006) Toxic potential of materials at the nanolevel. Science 311(5761):622-627. doi:10.1126 /science.1114397

Newman ME (2003) The structure and function of complex networks. SIAM Rev 45(2):167-256. doi:10.1137 /S003614450342480
Novoselov KS, Geim AK, Morozov SV, Jiang D, Zhang Y, Dubonos SA, Grigorieva IV, Firsov AA (2004) Electric field effect in atomically thin carbon films. Science 306(5696): 666-669. doi:10.1126/science.1102896

Noyons EC, Moed HF, Luwel M (1999) Combining mapping and citation analysis for evaluative bibliometric purposes: a bibliometric study. J Assoc Inf Sci 50(2):115-131. doi:10.1002/(SICI)1097-4571(1999)50:2<115::AID-ASI3 $>3.0 . \mathrm{CO} ; 2-\mathrm{J}$

Onyancha OB, Ocholla DN (2005) An informetric investigation of the relatedness of opportunistic infections to HIV/AIDS. Inform Process Manag 41(6):1573-1588. doi:10.1016/j. ipm.2005.03.015

Oregan B, Grätzel M (1991) A low-cost, high-efficiency solar cell based on dye-sensitized. Nature 353:737-740. doi:10.1038 $1353737 \mathrm{a} 0$

Ostrowski AD, Martin T, Conti J, Hurt I, Harthorn BH (2009) Nanotoxicology: characterizing the scientific literature, 2000-2007. J Nanopart Res 11(2):251-257. doi:10.1007 /s11051-008-9579-5

Pan ZW, Dai ZR, Wang ZL (2001) Nanobelts of semiconducting oxides. Science 291(5510):1947-1949. doi:10.1126 /science. 1058120

Peng X, Manna L, Yang W, Wickham J, Scher E, Kadavanich A, Alivisatos AP (2000) Shape control of CdSe nanocrystals. Nature 404(6773):59-61. doi:10.1038/35003535

Perdew JP, Burke K, Ernzerhof M (1996) Generalized gradient approximation made simple. Phys Rev Lett 77(18):3865. doi:10.1103/PhysRevLett.77.3865

Peters HPF, van Raan AF (1993) Co-word-based science maps of chemical engineering. Part I: representations by direct multidimensional scaling. Res Policy 22(1):23-45. doi:10.1016 /0048-7333(93)90031-C

Porter AL, Youtie J (2009) How interdisciplinary is nanotechnology? J Nanopart Res 11(5):1023-1041. doi:10.1007/s11051009-9607-0

Porter AL, Youtie J, Shapira P, Schoeneck D (2008) Refining search terms for nanotechnology. J Nanopart Res 10(5): 715-728. doi:10.1007/s11051-007-9266-y

Potter WG (1988) Of making many books there is no end: bibliometrics and libraries. J Acad Librariansh 14(4):238a$238 \mathrm{c}$

Qin X, Wang Z, Zhao H, Kaspersen LB (2016) The focus and frontier of corporate social responsibility: a co-word analysis of articles in SSCI, 2001-2014. Nankai Bus Rev Int 7(2): 130-149. doi:10.1108/NBRI-09-2015-0021

Rafols I, Porter AL, Leydesdorff L (2010) Science overlay maps: a new tool for research policy and library management. J Am Soc Inf Sci Tec 61(9):1871-1887. doi:10.1002/asi.21368

Sandison A (1989) Documentation note: thinking about citation analysis. J Doc 145(1):59-64. doi:10.1108/eb026839

Schummer J (2004) Multidisciplinarity, interdisciplinary, and patterns of research collaboration in nanoscience and nanotechnology. Scientometrics 59(3):425-465. doi:10.1023 /B:SCIE.0000018542.71314.38

Seaton A, Donaldson K (2005) Nanoscience, nanotoxicology, and the need to think small. Lancet 365(9463):923-924. doi:10.1016/S0140-6736(05)71061-8

Small H (1973) Co-citation in the scientific literature: a new measure of the relationship between two documents. J 
Am Soc Inform Sci 24(4):265-269. doi:10.1002 /asi.4630240406

Small H (1999) Visualizing science by citation mapping. J Assoc Inf Sci Tec 50(9):799-813. doi:10.1002/(SICI)1097-4571 (1999)50:9<799::AID-ASI9>3.0.CO;2-G

Small H, Griffith BC (1974) The structure of scientific literatures I: identifying and graphing specialties. Sci Stud 4(1):17-40. doi: $10.1177 / 030631277400400102$

Small H, Sweeney E (1985) Clustering the science citation index ${ }^{\circledR}$ using co-citations. I: a comparison of methods. Scientometrics 7(3-6):391-409. doi:10.1007/BF02017157

Small H, Sweeney E, Greenlee E (1985) Clustering the science citation index using co-citations. II: mapping science. Scientometrics 8(5-6):321-340. doi:10.1007/BF02018057

Soler JM, Artacho E, Gale JD, García A, Junquera J, Ordejón P, Sánchez-Portal D (2002) The SIESTA method for ab initio order-N materials simulation. J Phys-Condens Mat 14(11): 2745-2779. doi:10.1088/0953-8984/14/11/302

Soper ME, Osborne DL, Zweizig DL, Powell RR (1990) The librarian's thesaurus. American Library Association, Chicago

Suominen A, Li Y, Youtie J, Shapira P (2016) A bibliometric analysis of the development of next generation active nanotechnologies. J Nanopart Res 18(9):270. doi:10.1007 /s11051-016-3578-8

Sze SM (1981) Physics of semiconductor devices, 2nd edn. Wiley, Hoboken

Tans SJ, Verschueren AR, Dekker C (1998) Room-temperature transistor based on a single carbon nanotube. Nature 393(6680):49-52. doi:10.1038/29954

Terekhov AI (2012) Evaluating the performance of Russia in the research in nanotechnology. J Nanopart Res 14(11):1250. doi:10.1007/s11051-012-1250-5

Terekhov AI (2015) R \& D on carbon nanostructures in Russia: scientometric analysis, 1990-2011. J Nanopart Res 17(2):81. doi:10.1007/s11051-015-2897-5

Thomson Corporation (2015a) Journal Citation Report Science Edition 2014. https://jcr.incites.thomsonreuters.com. Accessed 15 April 2015

Thomson Corporation (2015b) Web of Science. http://webofknowledge.com. Accessed 21 July 2015

Tijseen RJW, De Leeuw J, Van Raan AFJ (1987) Quasicorrespondence analysis on scientometric transaction matrices. Scientometrics 11(5-6):351-366. doi:10.1007 /BF02279354

Tomajko KG, Drake MA (1985) The journal, scholarly communication, and the future. Ser Librarian 10(1-2):289-298. doi:10.1300/J123v10n0130

Troullier N, Martins JL (1991) Efficient pseudopotentials for plane-wave calculations. Phys Rev B 43(3):1993-2006. doi:10.1103/PhysRevB.43.1993

Van Den Besselaar P, Heimeriks G (2006) Mapping research topics using word-reference co-occurrences: a method and an exploratory case study. Scientometrics 68(3):377-393. doi:10.1007/s11192-006-0118-9

Van Eck NJ, Waltman L (2010) Software survey: VOSviewer, a computer program for bibliometric mapping. Scientometrics 84(2):523-538. doi:10.1007/s11192-009-0146-3

Van Eck NJ, Waltman L (2014a) CitNetExplorer: a new software tool for analyzing and visualizing citation networks. J Informetr 8(4):802-823. doi:10.1016/j.joi.2014.07.006

Van Eck NJ, Waltman L (2014b) CitnetExplorer [computer software]. Version 1.0.0. http://www.citnetexplorer.nl. Accessed 15 Jul 2015

Van Eck NJ, Waltman L, Dekker R, van den Berg J (2010) A comparison of two techniques for bibliometric mapping: multidimensional scaling and VOS. J Am Soc Inf Sci Tec 61(12):2405-2416. doi:10.1002/asi.21421

Van Eck NJ, Waltman L. (2015) VOSviewer [computer software]. Version 1.6.3. http://www.vosviewer.com. Accessed 10 Sept 2015

Van Raan AFJ, Tijseen RJW (1993) The neural net of neural network research: an exercise in bibliometric mapping. Scientometrics 26(1):169-192. doi:10.1007/BF02016799

Vargas-Quesada B, Moya-Anegón F, Chinchilla-Rodríguez Z, González-Molina A (2010) Showing the essential science structure of a scientific domain and its evolution. Inf Vis 9(4):288-300. doi:10.1057/ivs.2009.33

Wagner RS, Ellis WC (1964) Vapor-liquid-solid mechanism of single crystal growth (new method growth catalysis from impurity whisker epitaxial + large crystals Si E). Appl Phys Lett 4(5):89-90. doi:10.1063/1.1753975

Wang ZL, Song J (2006) Piezoelectric nanogenerators based on zinc oxide nanowire arrays. Science 312(5771):242-246. doi:10.1126/science. 1124005

White HD (2003) Pathfinder networks and author cocitation analysis: a remapping of paradigmatic information scientists. $J$ Am Soc Inf Sci Tec 54(5):423-434. doi:10.1002/asi.10228

Wood S, Jones R, Geldart A (2003) The social and economic challenges of nanotechnology. Economic and Social Research Council, London

Xia Y, Yang P, Sun Y, Wu Y, Mayers B, Gates B, Yin Y, Kim F, Yan H (2003) One-dimensional nanostructures: synthesis, characterization, and applications. Adv Mater 15(5):353389. doi:10.1002/adma.200390087

Yu WW, Qu L, Guo W, Peng X (2003) Experimental determination of the extinction coefficient of CdTe, CdSe, and CdS nanocrystals. Chem Mater 15(14):2854-2860. doi:10.1021 /cm034081k

Zhao D, Feng J, Huo Q, Melosh N, Fredrickson GH, Chmelka BF, Stucky GD (1998) Triblock copolymer syntheses of mesoporous silica with periodic 50 to 300 angstrom pores. Science 279(5350):548-552. doi:10.1126/science.279.5350.548 